\title{
SwissPedData: Standardising hospital records for the benefit of paediatric research
}

\author{
Manon Jaboyedoff ${ }^{\mathrm{ab} *}$, Milenko Rakic ${ }^{\mathrm{a} *}$, Sara Bachmann ${ }^{\mathrm{c}}$, Christoph Berger $^{\mathrm{d}}$, Manuel Diezi ${ }^{\mathrm{b}}$, Oliver Fuchs ${ }^{\mathrm{e}}$, Urs Frey ${ }^{\mathrm{c}}$, Alain \\ Gervaix $^{\mathrm{f}}$, Amalia Stefani Glücksberg ${ }^{\mathrm{g}}$, Michael Grotzer ${ }^{\mathrm{d}}$, Ulrich Heininger ${ }^{\mathrm{c}}$, Christian R. Kahlert ${ }^{\mathrm{h}}$, Daniela Kaiseri, Matthias V. \\ Kopp $^{\mathrm{e}}$, Roger Lauener ${ }^{\mathrm{h}}$, Thomas J. Neuhaus', Paolo Paioni ${ }^{\mathrm{d}}$, Klara Posfay-Barbe ${ }^{\mathrm{f}}$, Gian Paolo Ramelli ${ }^{\mathrm{g}}$, Umberto Simeoni ${ }^{\mathrm{b}}$, \\ Giacomo Simonetti $^{\mathrm{g}}$, Christiane Sokollik ${ }^{\mathrm{e}}$, Ben D. Spycher ${ }^{\mathrm{a} *}$, Claudia E. Kuehni ${ }^{\mathrm{a} *}$
}

a Institute of Social and Preventive Medicine (ISPM), University of Bern, Bern, Switzerland

b Service of Pediatrics, Department Women-Mother-Child, Lausanne University Hospital and University of Lausanne, Lausanne, Switzerland

c University of Basel Children's Hospital Basel (UKBB), University of Basel, Basel, Switzerland

d University Children's Hospital Zurich, University of Zurich, Zurich, Switzerland

e Department of Pediatrics, Inselspital, Bern University Hospital, University of Bern, Bern, Switzerland

f Department of Woman, Child and Adolescent, Geneva University Hospitals and Faculty of Medicine, Geneva, Switzerland

g Pediatric Department of Southern Switzerland, Ente Ospedaliero Cantonale, Bellinzona, Switzerland and Università della Svizzera Italiana, Lugano, Switzerland

h Children's Hospital of Eastern Switzerland, St. Gallen, Switzerland

i Children's Hospital of Lucerne, Cantonal Hospital Lucerne, Lucerne, Switzerland

* Contributed equally as first authors

** Contributed equally as last authors

\section{Summary}

BACKGROUND: Improvement of paediatric healthcare is hampered by inefficient processes for generating new evidence. Clinical research often requires extra encounters with patients, is costly, takes place in an artificial situation with a biased selection of patients, and entails long delays until new evidence is implemented into health care. Electronic health records (EHR) contain detailed information on real patients and cover the entirety of patients. However, the use of EHR for research is limited because they are not standardised between hospitals. This leads to disproportionate amounts of work for extracting data of interest and frequently data are incomplete and of poor quality.

AIMS: SwissPedData aims to lay the foundation for a paediatric learning health system in Switzerland by facilitating EHR-based research. In this project, we aimed to assess the way routine clinical data are currently recorded in large paediatric clinics in Switzerland and to develop a national EHR-based set of common data elements (CDEs) that covers all processes of routine paediatric care in hospitals.

METHODS: A taskforce of paediatricians from large Swiss children's hospitals reviewed the current status of routine data documentation in paediatric clinical care and the extent of digitalisation. We then used a modified Delphi method to reach a broad consensus on a national EHRbased set of CDEs.

Prof. Dr. med. Claudia

Kuehni

Institute of Social and

Preventive Medicine

University of Bern

Mittelstrasse 43

CH-3012 Bern

claudia.kuehni[at]

ispm.unibe.ch
RESULTS: All Swiss children's hospitals use EHR to document some or all aspects of care. One hundred and nineteen paediatricians, representing eight hospitals and all paediatric subspecialties, participated in an extended Delphi process to create SwissPedData. The group agreed on a national set of CDEs that comprises a main module with general paediatric data and sub-modules relevant to paediatric subspecialties. The data dictionary includes 336 CDEs: 76 in the main module on general paediatrics and between 11 and 59 CDEs per subspecialty module. Among these, 266 were classified as mandatory, 52 as recommended and 18 as optional.

CONCLUSION: SwissPedData is a set of CDEs for information to be collected in EHR of Swiss children's hospitals. It covers all care processes including clinical and paraclinical assessment, diagnosis, treatment, disposition and care site. All participating hospitals agreed to implement SwissPedData in their clinical routine and clinic information systems. This will pave the way for a national paediatric learning health system in Switzerland that enables fast and efficient answers to urgent clinical questions by facilitating high-quality nationwide retrospective and prospective observational studies and recruitment of patients for nested prospective studies and clinical trials.

\section{Introduction}

The creation of new evidence in medicine and the improvement of patient care are hampered by inefficient and laborious processes [1,2]. Most evidence is gathered through stand-alone research projects that are costly, timeconsuming, and conducted in an artificial research setting with a selected sample of patients. It also takes a long time for evidence to be implemented in health care [3]. Delays of many years are common, caused by the need to acquire research grants, recruit staff, obtain ethical approval, set up the study, recruit participants, collect and analyse data, 
write up and publish the results, and integrate these results into current standards of care. Paediatric research lags behind adult research for various reasons, including that the paediatric population is small, many paediatric health conditions are rare and ethical requirements are high. Given these constraints, results from studies in adults are often extrapolated to children $[4,5]$. However, because of the important changes that occur during their development, children differ fundamentally from adults in many aspects. These include large age-related differences in susceptibility to environmental influences, in disease manifestations, in the adequacy and performance of diagnostic tests, in drug disposition, and in responses to treatment [6].

The digitalisation of health records could significantly improve the evidence for paediatric medicine and rare diseases as it potentially allows easy and fast access to clinical data from routine patient encounters. It could make clinical research faster and cheaper and make its results more representative of the patients typically seen in health care. Electronic health records (EHR) are widely used in hospitals to document clinical and administrative information about patient encounters. Unfortunately, EHR are rarely standardised within and between institutions and data are often entered into open text fields, resulting in unstructured data. Research on rare diseases relies on data from multiple centres and is limited by the time and costs required to extract and recode these data into a common format. Such data abstraction is particularly challenging when the original data are unstructured $[7,8]$. Natural language processing and machine learning methods are increasingly being used to process unstructured data and make them available to research; however, many challenges remain [9]. Furthermore, retrospective standardisation often leads to a loss of information and impairment of data quality. These limitations could largely be circumvented if the original data were recorded in a structured and standardised way [10, 11]. A common EHR architecture allowing structured data capture during routine medical encounters could enable rapid analysis of healthcare data followed by speedy feedback of the knowledge generated into the same health care settings, a process called a learning health system $[12,13]$.

The aim of our project, which we have named SwissPedData, is to facilitate paediatric clinical research by improv-

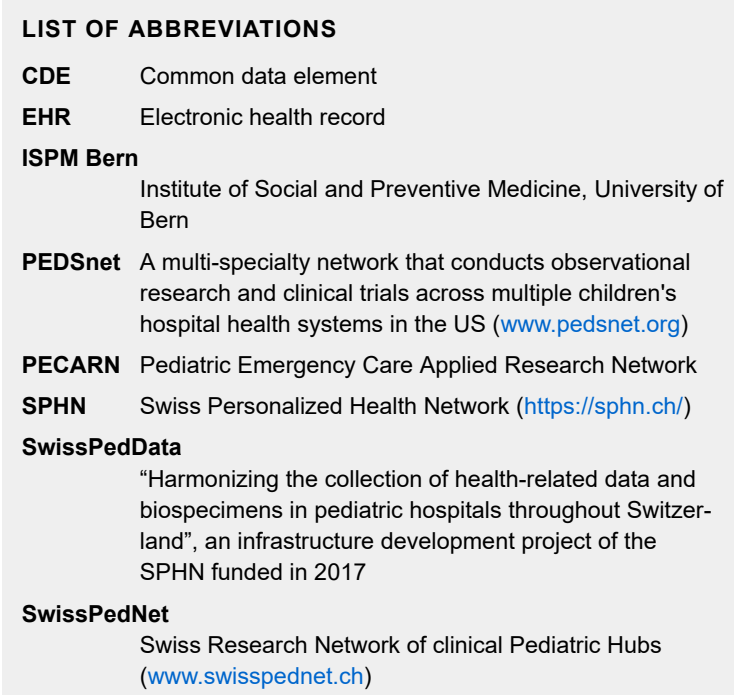

ing and standardising the quality of data generated by paediatric health care in Switzerland. To achieve this, we first assessed the status quo, i.e., the relevant aspects of paediatric care for which data are collected, the way these data are recorded, and the data management systems used in the participating paediatric hospitals in Switzerland. Second, we developed and approved a standardised paediatric set of common data elements (CDEs) for EHR across Switzerland by conducting a multi-stage consensus finding process among general paediatricians and paediatric subspecialists of university and cantonal children's hospitals. This paper describes the status quo of the project, the process of standardisation and the resulting set of CDEs: SwissPedData, Version 1.0.

\section{Methods}

\section{SwissPedData taskforce}

SwissPedNet, the research network of Swiss Children's hospitals (https://www.swisspednet.ch/home/), received an infrastructure grant from the Swiss Personalized Health Network (SPHN) to develop a common data structure in paediatric hospitals and launched SwissPedData with the support of the Swiss Society of Paediatrics (https://www.paediatrieschweiz.ch). SPHN, an initiative of the Swiss Federal Government, aims to achieve a nationwide interoperability of health data produced in university hospitals (https://sphn.ch). SPHN funds the development of infrastructures that make health data shareable for research, following a decentralised approach where data remain in each hospital. Data sharing should become possible either through the direct transfer of individual health data or through distributed analyses, whereby the data do not travel, but are processed decentrally by algorithms and then only data summaries and results are transferred to a central location [14]. SwissPedData is coordinated by a taskforce that consists of a core team at the Institute of Social and Preventive Medicine, University of Bern (ISPM Bern) and representatives from all participating hospitals (fig. 1). All the university hospitals (Basel, Bern, Geneva, Lausanne and Zurich) and three cantonal children's hospitals (Lucerne, St Gallen and Ticino) participated. The clinical directors of each hospital proposed one senior physician to represent the hospital's management board and one junior physician to represent the house officers and registrars who enter the most data into the EHR. The directors also suggested senior physicians representing general paediatrics and all major paediatric subspecialties for collaboration as experts on the Delphi panel. Each hospital suggested at least one expert for general paediatrics and one for each subspecialty. These were then contacted by the core team. Distinct panels were set up for the following subspecialties: paediatric cardiology, endocrinology, gastroenterology, allergy/immunology, infectious diseases, metabolic diseases, nephrology, neurology, pulmonology and rheumatology. Paediatric oncology and neonatology were considered separately because standardised datasets for these subspecialties have already been developed by the Swiss Neonatal Network \& Follow-Up Group (SwissNeoNet, https://www.neonet.ch/swissneonet) [15] and the Childhood Cancer Registry (https://www.childhoodcancerregistry.ch) [16]. Both datasets have been in use for 
many years and have been continuously refined and thus could be included directly in SwissPedData without further discussions. A related project is developing a set of CDEs for paediatric emergency medicine using the same approach. The results of that effort will be reported separately.

\section{SwissPedData scope}

SwissPedData focuses on the standardisation of the documentation of clinical encounters by paediatricians in children's hospitals. This documentation encompasses medical history, physical examination, investigations, diagnosis, treatment and procedures. It excludes laboratory data and biospecimens, as these types of data are usually not entered into EHR by the clinicians themselves. Other SPHN-funded projects are working towards the harmonization of laboratory data in Switzerland (https://sphn.ch/fr/network/project-overview/).

\section{Preparatory steps}

To prepare the ground for determining the new set of CDEs, the core team assessed the current status of clinical data documentation during routine encounters in participating hospitals and in ongoing clinical registries and cohort studies. They then searched the literature for other initiatives aiming to standardise paediatric EHR (fig. 2). The core team visited each participating hospital and collected clinical data entry forms and information on the EHR system used and on the degree of digitalisation of health records. The team identified any large existing national or regional clinical paediatric registries and cohort studies via the registry centre (https://www.paediatrieschweiz.ch/ swisspedregistry/) and the clinical hubs of SwissPedNet and through information obtained from the task force members of the participating hospitals. The core team collected metadata describing the datasets collected in these registries and cohort studies and investigated the content and format of the variables.

The core team also conducted a non-systematic, focused literature search to identify approaches to standardising paediatric data across multiple centres in other countries. The reference lists of the relevant publications identified were also scanned.

\section{Selection of candidate common data elements for SwissPedData}

Based on the information gained in the preparatory phase, the core team defined an initial list of CDEs to be considered for inclusion in the main module (general paediatrics) of SwissPedData. This was done based on an overview of the clinical data routinely documented in the hospitals; the variables collected in ongoing clinical cohort studies and registries; and the datasets of similar international initiatives. The initial list of CDEs was further refined during a two-day retreat held at the ISPM Bern with an interdisciplinary group including six paediatricians, three paediatric epidemiologists and two paediatric registry managers.

For each paediatric subspecialty, the initial list of candidate CDEs was drafted by the core team together with one hospital paediatrician who represented the subspecialty. This first draft was based on existing datasets specific to each subspecialty, such as large cohort studies or clinical registries, and/or on expert opinion (fig. 2, selection of candidate CDEs).

\section{Reaching a consensus: the Delphi process}

The consensus finding process aimed to reach agreement on 1) a list of CDEs for SwissPedData, 2) a standardised answer format for each CDE and 3) a classification of each $\mathrm{CDE}$ as either mandatory, recommended or optional. Starting with the initial selection of candidate CDEs, we implemented four Delphi rounds, consisting of one face-to-

Figure 1: SwissPedData taskforce.

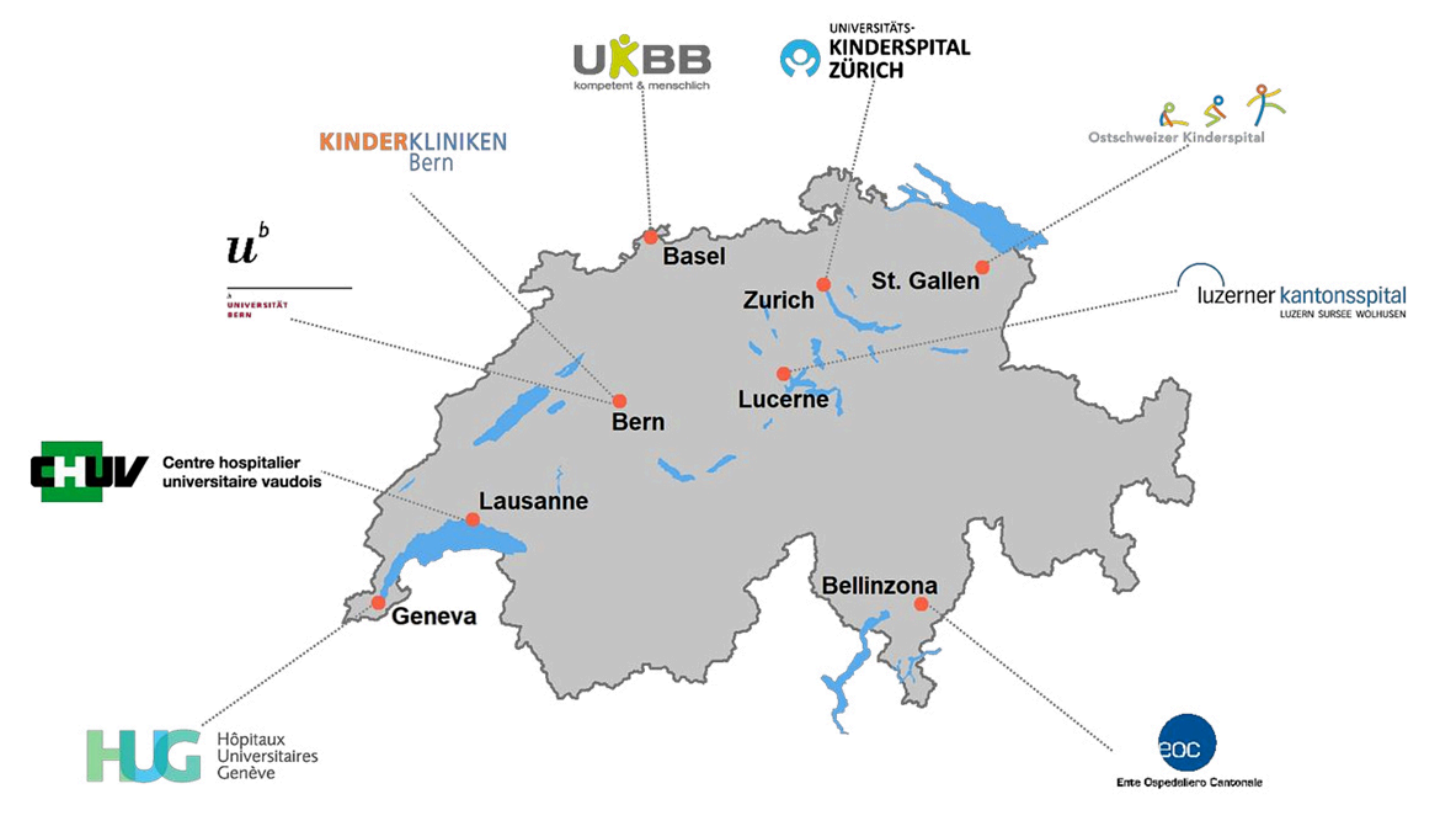


face meeting and three online surveys, to obtain a final set of CDEs based on a broad consensus (fig. 2). The Delphi method achieves consensus through a multi-round iterative process that involves eliciting opinions from experts and controlled feedback from the coordinating team $[17,18]$. The same basic scheme was followed for the main general paediatric module and for each of the subspecialty mod- ules. All experts were invited to each round, irrespective of whether or not they had given inputs in the previous rounds. For each online survey, the experts were asked to complete the questionnaire within two weeks. Those who had not responded within one week received a reminder email. The online surveys were programmed with the soft-

Figure 2: Consensus finding process followed to define SwissPedData, a set of CDEs for recording routine encounters in children's clinics in Switzerland. CDE: Common Data Element

\section{Preparatory steps}

\section{Source of variables}

a) Clinical forms used currently in the Swiss Children's hospitals

b) Existing clinical cohort studies and registries in Switzerland

c) Published datasets from similar initiatives, in particular PEDSnet

d) Suggestions from taskforce members

\section{Selection of candidate CDEs}

General paediatrics: Initial list (based on sources a, b and c) $(n=150)$ was refined during a 2-days interdisciplinary retreat oaf paediatricians, epidemiologists and registry managers.

Subspecialty modules: The core team drafted a list of candidate variables using existing datasets specific to each subspecialty (sources $a, b$ and $c$ ) in collaboration with one representative per subspecialty.

\section{Set up of the Delphi process}

Eleven working groups:

- One group for general paediatrics

- One group per subspecialty: cardiology, endocrinology, gastroenterology, immunoallergology, infectiology, metabolic diseases, nephrology, neurology, pulmonology, rheumatology

- Neonatology and paediatric oncology had already defined standard dataset prior to this project

- Paediatric emergency medicine is currently going through the procedure.

Experts were invited to each round, independent of their participation in previous rounds.

\section{Delphi process}

Round 1: Online survey (1 per subspecialty)

- Decision for inclusion or exclusion of candidate $\mathrm{CDEs}$, according to relevance for research and clinical work. Inclusion if $>80 \%$ agreed, exclusion if $>80 \%$ agreed. The others were classified as controversial.

- Included variables classified as mandatory, recommended or optional.

- Suggestion of new variables (classified all as controversial)

\begin{tabular}{l} 
Round 2: Face-to-face meeting (1 per subspecialty) \\
Discussion of all controversial CDEs (<80\% \\
agreement or variables newly suggested in first \\
round) until a group consensus was reached \\
- Definition of answer choices of included variables \\
$\begin{array}{l}\text { Round 3: Online survey (1 per subspecialty) } \\
\text { - } \quad \begin{array}{l}\text { Experts received excel file containing all the CDEs } \\
\text { They could propose to add new CDEs, delete CDEs, }\end{array} \\
\text { and define answer choices where they were missing } \\
\text { Round 4: Online survey (all participants) } \\
\text { All experts received the excel file containing the } \\
\text { paediatric core CDEs and all subspecialty CDEs } \\
\text { last input (minor suggestions) and final approval of } \\
\text { entire dataset }\end{array}$ \\
\hline
\end{tabular}

\section{SwissPedData, Version 1.0}

General paediatrics: 76 CDEs, Cardiology: 11 CDEs; Endocrinology: 59 CDEs; Gastroenterology: 17 CDEs; Allergy/lmmunology: 29 CDEs; Infectious diseases: 47 CDEs; Metabolic diseases: 20 CDEs; Nephrology: 34 CDEs; Neurology: 17 CDEs; Pulmonology: 31 CDEs; Rheumatology: 16 CDEs; Neonatology (SwissNeonet); Oncology (Childhood Cancer Registry); Paediatric Emergency care: ongoing 
ware SurveyMonkey Inc., San Mateo, California, USA and analysed using Microsoft Excel.

In the first round, the experts evaluated the candidate CDEs according to their relevance for research and clinical work (fig. 2, round 1). Each expert was asked to vote for the inclusion or exclusion of each candidate $\mathrm{CDE}$ and to suggest any additional CDEs. The questions were: "please state for each of the proposed variables (CDEs) below whether you think they should be included in this subspecialty module of SwissPedData" and "would you add other variables (CDEs)?". When opting for inclusion of a CDE, experts were further asked to classify the CDE as "mandatory", "recommended" or "optional". We retained CDEs that reached $80 \%$ for inclusion (designated as agreed) and excluded CDEs for which $80 \%$ of experts voted for exclusion. All other CDEs, including the additional CDEs suggested by the experts, were classified as "controversial". There is no standard level of consensus in the literature, but levels ranging from $50 \%$ to $80 \%$ are commonly used [ 19 , 20].

The second round consisted of face-to-face meetings, which were moderated by the core team and held at the ISPM Bern. During the face-to-face meetings, participants discussed all controversial CDEs and the additional CDEs suggested in the first online survey. They also agreed on standardised answer formats for the included CDEs. Eligible answer formats were a date, a date and time, a number, a binary response (e.g., yes/no), standardised response options or free text. When the discussions did not lead to a consensus, we used majority voting. Each face-to-face meeting lasted about three hours.

The third round was another e-Delphi survey, with participants being asked to check if key CDEs for their discipline were missing and to propose standardised answer formats or response options where these were missing.

In the fourth and final round, the agreed CDEs and answer formats were sent by email to all the experts for any last inputs and final approval.

Ethical approval was not required for this study, which did not involve the collection or use of patients' data.

\section{Results}

Current status of EHR in participating hospitals and existing initiatives aiming to standardize paediatric data

The eight participating hospitals were using different clinical systems for EHR from various vendors (table 1). Their degree of digitalisation varied: while some hospitals were using EHR for all care processes, others were only doing so for some. For example, all hospitals were recording clinical notes relating to inpatients electronically, but only half of them were using electronic drug prescriptions at the time of the survey.

We identified 5 paediatric cohort studies and 25 paediatric clinical registries with a nationwide or multiregional reach (appendix 1). The focused literature search identified four projects with similar goals in other countries, namely PECARN (Pediatric Emergency Care Applied Research Network), PHIS+ (Pediatric Health Information System), PROS (Pediatric Research in Office Settings) and PEDSnet. The initiative most similar to ours was PEDSnet, an American national paediatric learning health system that was founded in 2014 by eight children's hospitals, primarily to obtain child-specific data on the efficacy and safety of new and approved drugs [21] (https://pedsnet.org/data/). Currently, PEDSnet hosts analysis-ready, standardised longitudinal data from the primary, secondary and tertiary care of over 6.5 million patients. PEDSnet uses a common interoperable data platform that optimises the use of EHR, ensuring that data are entered once only. The collected data include demographics, vital status, encounters, diagnoses, vital signs, treatment and immunisations, among others (https://pedsnet.org/data/common-data-model/).

\section{Consensus finding process (Delphi method)}

Clinical directors proposed 121 experienced general paediatricians and subspecialists for the Delphi process, of whom 119 agreed to participate. Of these, 73 took part in the first round (online survey), 45 attended the second round (face-to-face meetings), 58 commented in the third round of the Delphi process and 68 gave their final approval of the dataset (appendix 2). The working groups contained between 7 and 14 members. All disagreements could be settled during the process through majority voting or through discussions. Most disagreements were about answer format rather than about which CDEs should be included in SwissPedData.

Table 1:

Electronic health records systems used in Swiss children's hospitals and digitalization of clinical documentation.

\begin{tabular}{|c|c|c|c|c|c|c|}
\hline \multirow[t]{2}{*}{ Children's hospital } & \multirow[t]{2}{*}{ Main IT system } & \multirow[t]{2}{*}{ Emergency clinical notes } & \multirow[t]{2}{*}{ Outpatient clinical notes } & \multicolumn{3}{|l|}{ Inpatient } \\
\hline & & & & Clinical notes & Drug prescription & Vital signs \\
\hline Basel & Phoenix & $E$ & $E+P$ & $E$ & $P$ & $E$ \\
\hline Bellinzona & DPI & $E$ & $E$ & $E$ & $E$ & $E$ \\
\hline Bern & ipdos & $E$ & $E+P$ & $E$ & $E$ & $E$ \\
\hline Geneva & DPI & $E$ & $E$ & $E$ & $E$ & $E$ \\
\hline Lausanne & Soarian & $E$ & $E$ & $E$ & $E$ & $E$ \\
\hline Luzern & Epic/LUKiS & $E$ & $E$ & $E$ & $E$ & $E$ \\
\hline St.Gallen & KISIM & $E$ & $E$ & $E$ & $\mathrm{P}$ & $E+P$ \\
\hline Zürich & Phoenix & $E$ & $E$ & $E$ & $E$ & $E$ \\
\hline
\end{tabular}

E: Electronic, P: Paper 


\section{SwissPedData (Version 1.0)}

SwissPedData consists of 336 CDEs: 76 in the main module on general paediatrics and between 11 and 59 in each of the 10 subspecialty modules (table 2 and appendix 3 ). The main module covers aspects concerning all paediatric patients, whether they are outpatients or inpatients. The subspecialty modules cover aspects specific to paediatric subspecialties that are not already covered by the main module. Each module is formally structured into the same nine domains representing all care processes: 1 . Care Site, 2. Demographics, 3. Medical History, 4. Physical Examination, 5. Clinical Scores, 6. Investigations, 7. Diagnosis, 8. Treatment, and 9. Equipment and Procedures. These represent domains commonly covered by EHR. The Care Site domain contains administrative data related to the hospital and to patient encounters. It includes type of admission, length of stay and scheduled follow-up. The Demographics domain contains demographic data, for example date of birth, gender, address, and country of birth. The Medical History and Physical Examination domains include clinical information such as birth history, family history, symptoms, medications and vital signs. The Clinical Scores domain contains specific scores, for example triage scale for emergency department patients or developmental tests. The Investigations domain contains data on investigations performed, such as lung function, renal ultrasound or blood glucose monitoring for patients with diabetes. The Diagnosis domain includes diagnosis and date of diagnosis, as well as diagnosis classifications such as Online Mendelian Inheritance in Man (OMIM) codes. The Treatment domain contains data on medications prescribed and administered in hospital, treatment adverse events and reasons for discontinuation of treatment. The Equipment and Procedures domain contains data on procedures performed on the patient, such as dialysis.

The full set of CDEs is shown in appendix 3, which provides a complete list of all agreed CDEs along with their description, answer format and standardised response options, and importance (mandatory, recommended or optional). Answer choices are number, binary or standardised options, or free text. When the "standardised option" format is used, specific value sets are defined. The CDEs will be implemented in children's hospital EHR depending on their importance, categorised as mandatory, recommended or optional. Mandatory CDEs must be implemented in EHR by all participating hospitals. Recommended CDEs should be implemented and optional CDEs may be implemented at the discretion of each hospital.

Examples of mandatory CDEs are vital parameters in the main module (general paediatrics) or "route of feeding" in the gastroenterology module. In the latter case, "route of feeding" will be recorded with standardised response options (oral, gastrostomy, naso/orogastric tube, intravenous, other). An example of a recommended CDE is "seizure type according to the ILEA 2017 classification of seizures" in the neurology module. "Opening pressure at lumbar puncture" is an optional CDE in the same module (appendix 3).

\section{Discussion}

We developed SwissPedData, a standardised national set of CDEs designed to collect clinical data during paediatric routine encounters in a harmonised way. It is the result of a broad consensus between general paediatricians and paediatric subspecialists from eight university and cantonal children's hospitals in Switzerland. It describes all processes of paediatric medical care including clinical and paraclinical assessment, diagnosis, treatment, disposition and care site. Each part of the dataset follows the usual structure of the EHR to allow easy implementation.

\section{Clinical data standardisation for a Swiss paediatric learning healthcare system}

SwissPedData aimed to standardise items up-front at the point of data entry. Prospective, standardised recording of routine clinical encounters avoids duplicate entry into research databases. However, this should not happen at the expense of an increase in documentation time by clinicians, a concern raised during our Delphi process. To avoid this pitfall, we focused primarily on data elements that are not only useful for research, but also for clinical work, and included CDEs that are routinely documented in paediatric EHR. SwissPedData is not comprehensive and much of the clinical documentation will remain unstandardised to preserve the rich narrative details that are difficult to capture in standardised fields but are nevertheless important for daily clinical work. These narrative data could be used by researchers applying text-mining approaches. SwissPedData could also be supplemented by questionnaires to patients and their families. The implementation of SwissPedData in EHR will include careful attention to clinician workflow to minimise potential negative consequences of standardisation.

Table 2:

Examples of common data elements (CDEs) of the core module (general paediatrics) of SwissPedData.

\begin{tabular}{|c|c|c|c|c|}
\hline Common data element & Format & Standardized response options & Importance & Comment / description \\
\hline $\begin{array}{l}\text { Follow-up after discharge / consul- } \\
\text { tation }\end{array}$ & $\begin{array}{l}\text { Standardised op- } \\
\text { tions }\end{array}$ & $\begin{array}{l}\text { General paediatrician, General practitioner, Subspecialist, } \\
\text { Nurse, None }\end{array}$ & Mandatory & Scheduled follow-up at discharge \\
\hline Country of birth & $\begin{array}{l}\text { Standardised op- } \\
\text { tions }\end{array}$ & $\begin{array}{l}\text { Swiss Federal Statistical Office: ISO code of the country of ori- } \\
\text { gin }\end{array}$ & Mandatory & Country of birth of the patient \\
\hline Birth weight & Number & & Mandatory & Weight at birth in $\mathrm{kg}$ \\
\hline Heart rate & Number & & Mandatory & Heart rate in beats per minute \\
\hline Glasgow Coma Scale & Number & & Mandatory & \\
\hline Indication for imaging study & Free text & & Mandatory & $\begin{array}{l}\text { Medical reason for the radiological } \\
\text { study }\end{array}$ \\
\hline Drug name & $\begin{array}{l}\text { Standardised op- } \\
\text { tions }\end{array}$ & International non-proprietary name & Mandatory & $\begin{array}{l}\text { Name of the drug(s) received as in- } \\
\text { patient }\end{array}$ \\
\hline Equipment date of insertion & Date & YYYY-MM-DD & Mandatory & \\
\hline
\end{tabular}


SwissPedData is designed to provide a basis for a paediatric learning health system in Switzerland in which clinical data from different children's hospitals can be combined to rapidly generate new knowledge relevant for day-to-day practice and translate it into improved health care for children. Existing learning health systems in other countries, such as PEDSnet in the US, have demonstrated that a paediatric learning health system can improve the health outcomes of children [22, 23]. Examples include the rapid identification of children suffering from glomerular diseases for clinical trials [24], comparing weight loss and safety among bariatric procedures using EHR data [25] and, recently, describing the epidemiology of paediatric patients infected by SARS-CoV-2 [26].

\section{Strengths and limitations}

The main strength of SwissPedData is that it is based on broad agreement between paediatricians from all university and cantonal paediatric clinics in Switzerland. The project received strong support from all clinical directors of Swiss children's hospitals, from the paediatric research network SwissPedNet and from more than 100 experienced paediatricians who participated in its development. SwissPedData emphasises the prospective collection of standardised data, which can greatly reduce the time and costs needed for data preparation and analysis as it avoids the need for retrospective standardisation or double entry. Our consensus finding approach could be adapted for use by other medical specialties that wish to define CDEs in the future.

SwissPedData has a number of omissions that are intentional. First, we focused on standardising a minimal set of items that are particularly relevant and specific to paediatric routine care. SwissPedData will thus not replace existing terminologies for clinical health care such as SNOMED-CT. Rather, standardised data from SwissPedData can in the future be mapped to SNOMED-CT. Second, SwissPedData does not include laboratory data or detailed radiological data. However, other projects within the SPHN are working on the standardisation of these domains. The goal is to link the standardised paediatric data extracted from EHR with laboratory data standardised thanks to other SPHN projects like L4CHLAB. Such linkage can be done through hospital patient IDs, or with birth dates and names. Third, SwissPedData will need to be translated into the Swiss national languages before implementation in children's hospital EHR.

\section{SwissPedData is adapted to the Swiss context}

The Swiss healthcare system is decentrally structured, with cantons being responsible for the organisation of local health care, and therefore is highly heterogeneous. As a consequence, children's clinics are relatively small, with catchment areas of a few 100,000 children. Obtaining sufficient patient samples for research is only possible by combining data from multiple hospitals, especially for rare conditions. However, given the differences in EHR and IT systems between hospitals, this results in long delays and huge costs for obtaining, extracting, standardising and cleaning the heterogeneous data. SwissPedData, once implemented in all children's clinics, will allow researchers to identify and recruit patients for clinical trials in real time, to conduct retrospective studies with high-quality data, and to conduct nested prospective studies. As examples, participants of the "Clinical Data for Paediatric Research: the Swiss Approach" symposium held in 2019 drafted sketches of the following research projects based on SwissPedData: a diagnostic study on the validity of the tests used for auditory screening in newborns; a benchmarking study assessing the quality of treatment for bronchiolitis across different children's hospitals; a cohort study on the incidence of hearing loss after treatment with aminoglycosides in infancy; a cohort study on kidney injury after treatment with acyclovir; and a randomised clinical trial comparing the effectiveness of different treatment regimens for type 1 diabetes. Some of these project sketches suggested complementing the hospital dataset with available data from other sources such as the federal statistical office or laboratory data, or through the collection of additional data through questionnaires or specific examinations.

\section{Comparison with other projects}

SwissPedData is closely aligned with PEDSnet, a USbased paediatric clinical data research network [21]. PEDSnet includes eight children's hospitals that provide care for $2.8 \%$ of the paediatric population in the USA (2.1 million patients) [21]. The database contains standardised clinical data from EHR covering 6.5 million children (https://pedsnet.org/) and forms the basis of a high-quality research programme and learning health system. Studies based on PEDSnet data cover a wide range of research topics and study designs in paediatrics, including descriptive epidemiology [27], computable phenotyping [24], longitudinal observational studies [28] and comparative effectiveness [29]. PEDSnet established a common data model (PEDSnet CDM) from the beginning of their network, based on the Observational Health Data Sciences and Informatics collaborative's OMOP common data model. With SwissPedData, we defined a list of priority CDEs that can be mapped to SNOMED-CT in the future.

PEDSnet may also serve as a role model for the implementation of SwissPedData and has already demonstrated its usefulness for observational and interventional research and for the standardisation of care processes. Each hospital that participates in PEDSnet regularly extracts the standardised data from its EHR in a predefined way [21].

Another notable example of harmonised clinical datasets in paediatrics is the Pediatric Emergency Care Applied Research Network (PECARN), an EHR-based registry that has harmonised data in the paediatric emergency setting in seven American paediatric emergency departments to make it usable for paediatric research. PECARN uses data resources from seven paediatric emergency departments of four hospitals [30].

\section{Outlook and next steps}

All participating hospitals are committed to implementing SwissPedData in their EHR by 2024. A committee of clinicians and IT specialists in each hospital will supervise the implementation process. The EHR of children's hospitals will be restructured at the front-end to include SwissPedData CDEs. Practically, this means that EHR as seen by their users (physicians) will include the CDEs of Swis- 
sPedData. For some hospitals, where this is not possible in the short term, we will also offer the possibility of transforming the source data to the CDEs and contributing it to the common dataset. SwissPedData is intended to evolve and be adaptive to existing needs. The set of CDEs can be expanded to cover more domains or to include more CDEs per domain. Temporary CDEs can be added for nested research projects. Self-completed or parent-completed questionnaires can add information relating to a child's family and home environment, which is not routinely recorded in EHR. Data from primary care encounters could also be integrated in the future.

In ongoing work, other prerequisites for the implementation of SwissPedData are being put into place: a general consent form for use of the data from patients and caregivers, a data transfer and use agreement (DTUA) between the clinics, and protocols for obtaining ethics approval for SwissPedData overall and for individual research projects. Some aspects are being dealt with within other infrastructure development projects of the SPHN network (www.sphn.ch), namely the C3-Study (citizen centred consent) project and the E-General Consent project. Furthermore, the SPHN provides legal agreement templates, including a DTUA and an ethical framework for all its projects. It is important to stress that only data useful for the clinical management of the patient will be recorded and that these data will always be stored by each children's hospital as part of the patient's file. The only difference to the previous procedure is that some of these clinical data will be recorded in a standardised way. To have access to these data for research, researchers will have to get ethical approval as usual.

It is planned that SwissPedData will be implemented as a project on the SPHN infrastructure for data exchange, so that data can in future be accessed through a central portal. The SPHN Data Coordination Centre and BioMedIT (https://sphn.ch/network/projects/biomedit/) can provide assistance and the infrastructure for this. The aim is to keep SwissPedData CDEs harmonized with the future releases of the SPHN dataset (https://sphn.ch/services/documents/ technical-documents/). An additional central coordination center for paediatric research should facilitate communication between children's clinics, international research partners and funders, and also assist researchers in writing grant applications, obtaining ethical approval and accessing the necessary datasets. The resources needed to maintain SwissPedData will require the support of a central coordination center encompassing an experienced researcher ideally with a background in paediatrics, an IT specialist, andlocal support of the responsible clinicians and IT specialists in each hospital. Funding for the implementation and maintenance of SwissPedData will need to be secured. Potential funding sources are participation in suitable calls for proposals, charging cost-covering fees for services provided by SwissPedData and collaboration with industry, for example for post-marketing studies. Collaborations with international partners such as PEDSnet are foreseen, and first exchanges have occurred.

In conclusion, SwissPedData defines a set of common data elements (CDEs) for clinical paediatric care based on a broad agreement among university and cantonal paediatric hospitals in Switzerland. With SwissPedData, Swiss chil- dren's hospitals will be able to provide researchers with standardized, high-quality routine clinical paediatric data in the near future. SwissPedData will provide the basis for a learning health system for paediatric care in Switzerland.

\section{Acknowledgments}

We thank all the experts who participated in the Delphi process, SwissPedNet, College A, the Swiss Personalized Health Network (SPHN), and ISPM Bern staff: Alexander Laemmle, Alexander Moeller, Alexandra Wilhelm-Bals, Alexandre Datta, Alice Koehli, Andrea Duppenthaler, Andreas Nydegger, Andreas Worner, Anita Rauch, Anna Wefers, Anne Tscherter, Arnaud Merglen, Barbara Goeggel Simonetti, Juerg Barben, Birgit Donner, Caroline Roduit, Christian Braegger, Christian Kahlert, Christian Korff, Christian Huemer, Christian Lovis, Christina Schindera, Christoph Aebi, Christoph Berger, Christophe Folly, Christoph Rudin, Christian Balmer, Cristina Ardura, Claudia Boettcher, Constance Barazzone-Argiroffo, Corinna Leoni Foglia, Dagmar L'Allemand, Daniel Konrad, Daniel Trachsel, Daniela MarxBerger, Diana Ballhausen, Dirk Fischer, Dominik Stambach, Eliane Roulet, Elvira Cannizzaro, Emanuela Valsangiacomo, Eva Pedersen, Federica Vanoni, Felicitas Bellutti, Florian Bauder, Florence Barbey, Florian Singer, François Cachat, Franziska Kunz, Gabor Szinnai, Georg Marx, Giovanni Ferrari, Gianluca Gualco, Guido Laube-Bless, Hans Peter Kuen, Hassib Chehade, Ilse Kern, Isabel Bolt, Isabelle Rochat, Jana Pachlopnik Schmid, Jean-Baptiste Armengaud, JeanChristoph Caubet, Joan Carles Suris Granell, Joël Fluss, Johannes Spalinger, Julien Caccia, Jürg Hammer, Kanetee Busiah, Katrin Heldt, Katharina Flandera, Kristina Keitel, Laetitia Marie Petit, Lisa Kottanattu, Lorenzo Zgraggen, Luca Garzoni, Matthias Horn, Maria Otth, Matthias Baumgartner, Matthias Gautschi, Maura Zanolari-Calderari, Maurice Beghetti, Melanie Hess, Michael Hauschild, Michael Buettcher, Michael Hofer, Mirjam Dirlewanger, Myrofora Goutaki, Nicolas Regamey, Nicolas Waespe, Nicole Sekarski, Nicole Ritz, Noémie Wagner, Oliver Niesse, Oswald Hasselmann, Paloma Parvex, Paolo Tonella, Paolo Paioni, Pascale Wenger, Peter Weber, Philip Broser, Philipp Agyman, Philip Do Canto, Philippe Steenhout, Philippe Eigenmann, Piero Balice, Pierre-Alex Crisinel, Raoul Furlano, Rebeca Mozun, Regula Laux, Regina Wespi, Robert Steinfeld, Sabine Pallivathukal, Sandra Asner, Sebastian Grunt, Sébastien Lebon, Sébastien Papis, Selina Pinosch, Sibylle Tschumi, Stefano di Bernardo, Sylvain Blanchon, Thomas Schmitt-Mechelke, Ulrike Halbsguth, Urs Zumsteg, Valérie Schwitzgebel, Valérie McLin, Verena Pfeiffer and Yacine Aggoun.

\section{Financial disclosure}

This study is funded by the Swiss Personalized Health Network (SPHN) [2017DEV14] and by the University of Bern (matched funding)

\section{References}

1. Califf RM, Robb MA, Bindman AB, Briggs JP, Collins FS, Conway PH, et al. Transforming Evidence Generation to Support Health and Health Care Decisions. N Engl J Med. 2016 Dec;375(24):2395-400. http://dx.doi.org/10.1056/NEJMsb1610128. PubMed. 1533-4406

2. Khozin S, Blumenthal GM, Pazdur R; Real-world Data for Clinical Evidence Generation in Oncology. Real-world Data for Clinical Evidence Generation in Oncology. J Natl Cancer Inst. 2017 Nov;109(11). http://dx.doi.org/10.1093/jnci/djx187. PubMed. 1460-2105

3. Wensing M, Grol R. Knowledge translation in health: how implementation science could contribute more. BMC Med. 2019 May;17(1):88 http://dx.doi.org/10.1186/s12916-019-1322-9. PubMed. 1741-7015

4. Kern SE. Challenges in conducting clinical trials in children: approaches for improving performance. Expert Rev Clin Pharmacol. 2009 Nov;2(6):609-17. http://dx.doi.org/10.1586/ecp.09.40. PubMed. 1751-2441

5. The Lancet Diabetes Endocrinology. Spotlight on rare diseases. Lancet Diabetes Endocrinol. 2019 Feb;7(2):75. http://dx.doi.org/10.1016/ S2213-8587(19)30006-3. PubMed. 2213-8595

6. Davis MM. Stunting the growth of child health research: a need to reframe "children are not small adults". JAMA Pediatr. 2013 Jul;167(7):598-9. http://dx.doi.org/10.1001/jamapediatrics.2013.165. PubMed. 2168-6211

7. Polnaszek B, Gilmore-Bykovskyi A, Hovanes M, Roiland R, Ferguson P, Brown R, et al. Overcoming the Challenges of Unstructured Data in Multisite, Electronic Medical Record-based Abstraction. Med Care. 
2016 Oct;54(10):e65-72. http://dx.doi.org/10.1097/

MLR.0000000000000108. PubMed. 1537-1948

8. Ogunyemi OI, Meeker D, Kim HE, Ashish N, Farzaneh S, Boxwala A. Identifying appropriate reference data models for comparative effectiveness research (CER) studies based on data from clinical information systems. Med Care. 2013 Aug;51(8 Suppl 3):S45-52. http://dx.doi.org/ 10.1097/MLR.0b013e31829b1e0b. PubMed. 1537-1948

9. Tayefi M, et al. Challenges and opportunities beyond structured data in analysis of electronic health records. WIREs Computational Statistics. $\mathrm{n}$ / a(n/a): p. e1549.

10. Kush R, Alschuler L, Ruggeri R, Cassells S, Gupta N, Bain L, et al. Implementing Single Source: the STARBRITE proof-of-concept study. J Am Med Inform Assoc. 2007 Sep-Oct;14(5):662-73. http://dx.doi.org/ 10.1197/jamia.M2157. PubMed. 1067-5027

11. Breil B, Semjonow A, Müller-Tidow C, Fritz F, Dugas M. HIS-based Kaplan-Meier plots-a single source approach for documenting and reusing routine survival information. BMC Med Inform Decis Mak. 2011 Feb;11(1):11. http://dx.doi.org/10.1186/1472-6947-11-11. PubMed. 1472-6947

12. Seid M, Margolis PA, Opipari-Arrigan L. Engagement, peer production, and the learning healthcare system. JAMA Pediatr. 2014 Mar;168(3):201-2. http://dx.doi.org/10.1001/jamapediatrics.2013.5063. PubMed. 2168-6211

13. Institute of Medicine Roundtable on Evidence-Based. M., The National Academies Collection: Reports funded by National Institutes of Health, in The Learning Healthcare System: Workshop Summary, L. Olsen, D. Aisner, and J.M. McGinnis, Editors. 2007, National Academies Press (US)

14. Toh S, Rifas-Shiman SL, Lin PD, Bailey LC, Forrest CB, Horgan CE, et al.; PCORnet Antibiotics and Childhood Growth Study Group. Privacyprotecting multivariable-adjusted distributed regression analysis for multi-center pediatric study. Pediatr Res. 2020 May;87(6):1086-92. http://dx.doi.org/10.1038/s41390-019-0596-0. PubMed. 1530-0447

15. Adams M, Bucher HU. Neonatologie: Ein früher Start ins Leben: Was bringt ein nationales Register? Schweiz Med Forum. 2013;13(3):35-7. http://dx.doi.org/10.4414/smf.2013.01397. 1424-4020

16. Michel G, von der Weid NX, Zwahlen M, Adam M, Rebholz CE, Kuehni CE; Swiss Childhood Cancer Registry; Swiss Paediatric Oncology Group (SPOG) Scientific Committee. The Swiss Childhood Cancer Registry: rationale, organisation and results for the years 2001-2005. Swiss Med Wkly. 2007 Sep;137(35-36):502-9. PubMed. 1424-7860

17. Jones J, Hunter D. Consensus methods for medical and health services research. BMJ. 1995 Aug;311(7001):376-80. http://dx.doi.org/10.1136/ bmj.311.7001.376. PubMed. 0959-8138

18. Dalkey NC. The Delphi method: An experimental study of group opinion. 1969, RAND CORP SANTA MONICA CALIF.

19. Hasson F, Keeney S, McKenna H. Research guidelines for the Delphi survey technique. J Adv Nurs. 2000 Oct;32(4):1008-15. PubMed. 0309-2402
20. Walker MA, Selfe MJ. The Delphi method: a useful tool for the allied health researcher. Br J Ther Rehabil. 1996;3(12):677-81. http://dx.doi.org/10.12968/bjtr.1996.3.12.14731. 1354-8581

21. Forrest CB, Margolis PA, Bailey LC, Marsolo K, Del Beccaro MA, Finkelstein JA, et al. PEDSnet: a National Pediatric Learning Health System. J Am Med Inform Assoc. 2014 Jul-Aug;21(4):602-6. http://dx.doi.org/10.1136/amiajnl-2014-002743. PubMed. 1527-974X

22. Ramsey LB, Mizuno T, Vinks AA, Margolis PA. Learning Health Systems as Facilitators of Precision Medicine. Clin Pharmacol Ther. 2017 Mar;101(3):359-67. http://dx.doi.org/10.1002/cpt.594. PubMed. $1532-6535$

23. Deans KJ, Sabihi S, Forrest CB. Learning health systems. Semin Pediatr Surg. 2018 Dec;27(6):375-8. http://dx.doi.org/10.1053/j.sempedsurg.2018.10.005. PubMed. 1532-9453

24. Denburg MR, Razzaghi H, Bailey LC, Soranno DE, Pollack AH, Dharnidharka VR, et al.; Using Electronic Health Record Data to Rapidly Identify Children with Glomerular Disease for Clinical Research. Using Electronic Health Record Data to Rapidly Identify Children with Glomerular Disease for Clinical Research. J Am Soc Nephrol. 2019 Dec;30(12):2427-35. http://dx.doi.org/10.1681/ASN.2019040365. PubMed. 1533-3450

25. Arterburn D, Wellman R, Emiliano A, Smith SR, Odegaard AO, Murali S, et al.; PCORnet Bariatric Study Collaborative. Comparative Effectiveness and Safety of Bariatric Procedures for Weight Loss: A PCORnet Cohort Study. Ann Intern Med. 2018 Dec;169(11):741-50. http://dx.doi.org/10.7326/M17-2786. PubMed. 1539-3704

26. Bailey LC, Razzaghi H, Burrows EK, Bunnell HT, Camacho PE, Christakis DA, et al. Assessment of 135794 Pediatric Patients Tested for Severe Acute Respiratory Syndrome Coronavirus 2 Across the United States. JAMA Pediatr. 2021 Feb;175(2):176-84. http://dx.doi.org/ 10.1001/jamapediatrics.2020.5052. PubMed. 2168-6211

27. Bailey LC, Milov DE, Kelleher K, Kahn MG, Del Beccaro M, Yu F, et al. Multi-Institutional Sharing of Electronic Health Record Data to Assess Childhood Obesity. PLoS One. 2013 Jun;8(6):e66192-66192. http://dx.doi.org/10.1371/journal.pone.0066192. PubMed. 1932-6203

28. Lang JE, Bunnell HT, Hossain MJ, Wysocki T, Lima JJ, Finkel TH, et al. Being Overweight or Obese and the Development of Asthma. Pediatrics. 2018 Dec;142(6):e20182119. http://dx.doi.org/10.1542/ peds.2018-2119. PubMed. 1098-4275

29. Inge TH, Coley RY, Bazzano LA, Xanthakos SA, McTigue K, Arterburn D, et al.; PCORnet Bariatric Study Collaborative. Comparative effectiveness of bariatric procedures among adolescents: the PCORnet bariatric study. Surg Obes Relat Dis. 2018 Sep;14(9):1374-86. http://dx.doi.org/10.1016/j.soard.2018.04.002. PubMed. 1878-7533

30. Deakyne Davies SJ, Grundmeier RW, Campos DA, Hayes KL, Bell J, Alessandrini EA, et al.; Pediatric Emergency Care Applied Research Network. The Pediatric Emergency Care Applied Research Network Registry: A Multicenter Electronic Health Record Registry of Pediatric Emergency Care. Appl Clin Inform. 2018 Apr;9(2):366-76. http://dx.doi.org/10.1055/s-0038-1651496. PubMed. 1869-0327 


\section{Appendix}

Appendix 1: Paediatric registries and cohort studies in Switzerland

\section{Registry / Cohort Study}

Childhood Cancer Registry ChCR

Swiss Primary Ciliary Dyskinesia Registry (SPCDR)

Swiss Cerebral Palsy Registry (Swiss-CP-Reg)

Swiss Growth Registry (SGR)

Swiss Paediatric Airway Cohort (SPAC)

National

Swiss Paediatric Renal Registry (SPRR)

National

Swiss Rare Disease Registry (SRDR)

National

Swiss Registry for Neuro-Muscular

Cystic Fibrosis (CF) newborn screening

Juvenile Inflammatory Rhumatism cohort (JIRcohorte)

National

SwissNeoNet Minimal Neonatal Data Set (MNDS)

SwissNeoNet National Asphyxia and Cooling Registry (ASP)

Swiss NeoNet Follow-Up (FU)

Swiss NeuroPaediatric Stroke Registry (SNPSR)

Swiss Congenital Lung Anomalies (CLA) Registry

Swiss Mother and Child HIV Cohort Study (MoCHiV)

Swiss Cystic Fibrosis Infant Lung Development (SCILD) cohort

National

Swiss Pediatric Surveillance Unit (SPSU)

Swiss Hemophilia Registry (SHN)

National

COST Action BM1105 Patient Registry - GnRH Network

National

Registry of congenital anomalies in the canton of Vaud

National

Swiss Cleft lip and Palate Registry

National

European

National

National

National

National

National

National

National

National

National

European

National

National 


\begin{tabular}{|l|l|l|l|l|l|l|l|l|l|l}
\hline Swiss Biliary Atresia Registry & National \\
\hline Swiss registry on Autoimmune Hepatitis & National \\
\hline European Registry for Primary Immunodeficiencies (ESID registry) & European \\
\hline European Cystic Fibrosis Patient Registry (ECFSPR) & European \\
\hline European Childhood Interstitial Lung Disease (chILD-EU) Registry & European \\
\hline Swiss Inflammatory Bowel Disease Pediatric Cohort Study (Swiss IBD Pediatric Cohort Study) & National \\
\hline Splenectomy Registry & Global \\
\hline Pediatric and Adult Intercontinental Registry on Chronic ITP (PARC-ITP registry) & Global \\
\hline Diabetes Patienten Verlaufsdokumentation Registry (DPV) & European \\
\hline
\end{tabular}




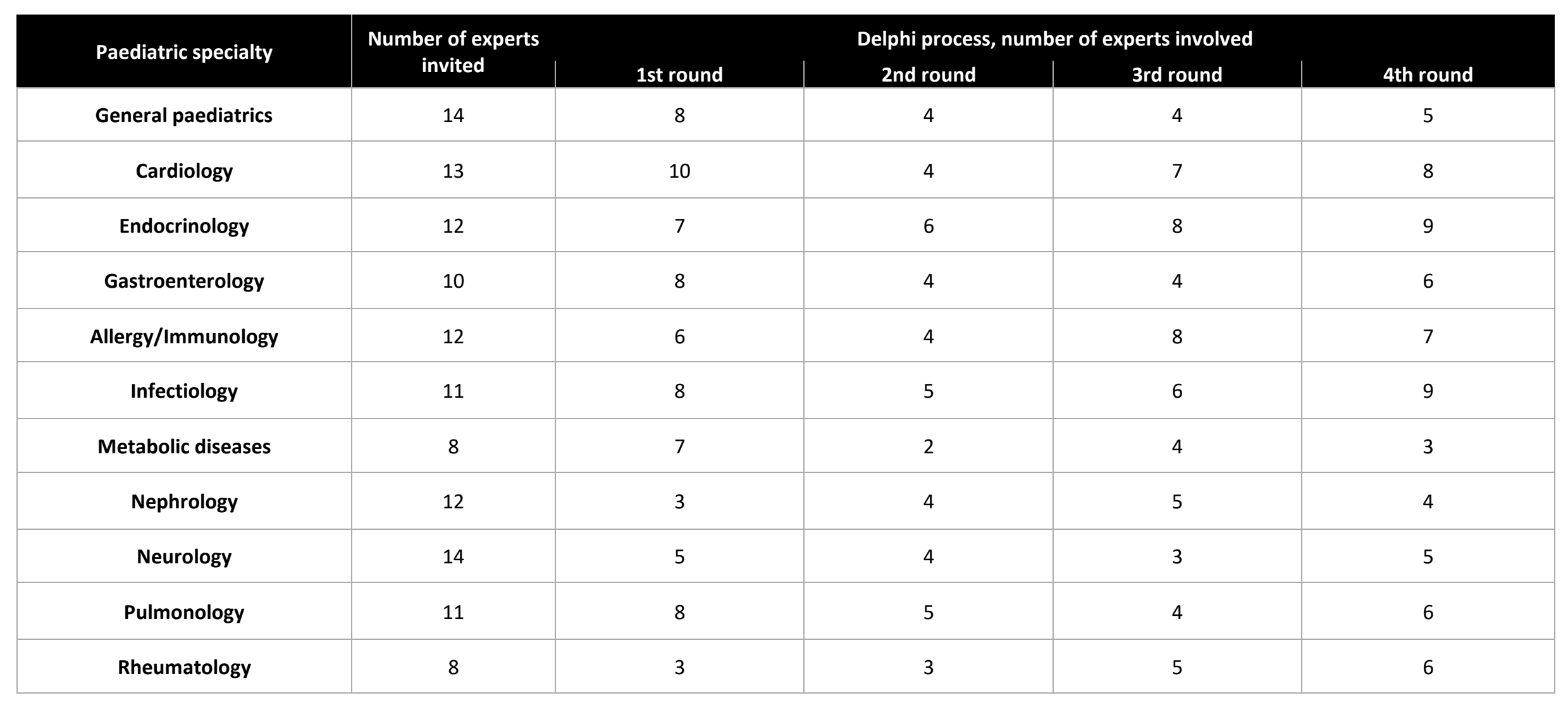


Appendix 3 : SwissPedData Common Data Model (CDM), Version 1.0

\begin{tabular}{|c|c|c|c|c|c|}
\hline Module(s) & Common Data Element & Format & Standardized response options & Importance & $\begin{array}{l}\text { Comment / } \\
\text { Description }\end{array}$ \\
\hline \multicolumn{6}{|l|}{ Domain: Care site } \\
\hline General paediatrics & Type of admission & $\begin{array}{l}\text { standardized } \\
\text { options }\end{array}$ & $\begin{array}{l}\text { Elective admission } \\
\text { Emergency admission }\end{array}$ & Mandatory & \\
\hline General paediatrics & Provenance & $\begin{array}{l}\text { standardized } \\
\text { options }\end{array}$ & $\begin{array}{l}\text { Other hospital } \\
\text { Emergency department } \\
\text { Home } \\
\text { Other }\end{array}$ & Mandatory & \\
\hline General paediatrics & Care Handling Type & $\begin{array}{l}\text { standardized } \\
\text { options }\end{array}$ & $\begin{array}{l}\text { Inpatient } \\
\text { Outpatient }\end{array}$ & Mandatory & \\
\hline General paediatrics & Visit start date and time & datetime & YYYY-MM-DD hh:mm:ss & Mandatory & $\begin{array}{l}\text { Datetime at which } \\
\text { the interaction } \\
\text { between individual } \\
\text { and the care provider } \\
\text { institute started }\end{array}$ \\
\hline General paediatrics & Visit end date and time & datetime & YYYY-MM-DD hh:mm:ss & Mandatory & $\begin{array}{l}\text { Datetime at which } \\
\text { the interaction } \\
\text { between individual } \\
\text { and the care provider } \\
\text { institute stopped }\end{array}$ \\
\hline General paediatrics & Datetime of admission & datetime & YYYY-MM-DD hh:mm:ss & Mandatory & $\begin{array}{l}\text { Datetime of patient's } \\
\text { admission to the care } \\
\text { provider institute }\end{array}$ \\
\hline General paediatrics & Discharge destination & $\begin{array}{l}\text { standardized } \\
\text { options }\end{array}$ & $\begin{array}{l}\text { Home } \\
\text { Other hospital } \\
\text { Institution } \\
\text { Other }\end{array}$ & Mandatory & $\begin{array}{l}\text { Location to which the } \\
\text { patient is discharged }\end{array}$ \\
\hline General paediatrics & Follow-up after discharge / consultation & $\begin{array}{l}\text { standardized } \\
\text { options }\end{array}$ & $\begin{array}{l}\text { General paediatrician } \\
\text { General practitioner } \\
\text { Subspecialist } \\
\text { Nurse } \\
\text { None }\end{array}$ & Mandatory & $\begin{array}{l}\text { Scheduled follow-up } \\
\text { at discharge }\end{array}$ \\
\hline General paediatrics & Translator needed & $\begin{array}{l}\text { standardized } \\
\text { options }\end{array}$ & $\begin{array}{l}\text { Yes } \\
\text { No } \\
\text { Unknown }\end{array}$ & $\begin{array}{l}\text { Recommende } \\
\text { d }\end{array}$ & $\begin{array}{l}\text { Translator needed } \\
\text { for communication } \\
\text { between patient and } \\
\text { healthcare team }\end{array}$ \\
\hline General paediatrics & Hospital & $\begin{array}{l}\text { standardized } \\
\text { options }\end{array}$ & See comments & Mandatory & $\begin{array}{l}\text { Standardized } \\
\text { response options will } \\
\text { be name of } \\
\text { participating } \\
\text { children's hospitals }\end{array}$ \\
\hline
\end{tabular}




\begin{tabular}{|c|c|c|c|c|c|}
\hline Module(s) & Common Data Element & Format & Standardized response options & Importance & $\begin{array}{l}\text { Comment / } \\
\text { Description }\end{array}$ \\
\hline General paediatrics & Department & $\begin{array}{l}\text { standardized } \\
\text { options }\end{array}$ & See comments & Mandatory & $\begin{array}{l}\text { Standardized } \\
\text { response options will } \\
\text { be name of } \\
\text { departments of } \\
\text { participating } \\
\text { children's hospitals }\end{array}$ \\
\hline General paediatrics & Unit & $\begin{array}{l}\text { Standardized } \\
\text { options }\end{array}$ & See comments & Mandatory & $\begin{array}{l}\text { Standardized } \\
\text { response options will } \\
\text { be name of units of } \\
\text { participating } \\
\text { children's hospitals }\end{array}$ \\
\hline Infectious diseases & If coming from another hospital: Country & $\begin{array}{l}\text { standardized } \\
\text { options }\end{array}$ & $\begin{array}{l}\text { Swiss Federal Statistical Office: ISO code of the } \\
\text { country of origin }\end{array}$ & Mandatory & $\begin{array}{l}\text { Country of } \\
\text { originating hospital }\end{array}$ \\
\hline \multicolumn{6}{|c|}{ Domain: Demographics } \\
\hline General paediatrics & Patient Datetime of birth & datetime & YYYY-MM-DD hh:mm:ss & Mandatory & $\begin{array}{l}\text { Datetime of birth of } \\
\text { the patient }\end{array}$ \\
\hline General paediatrics & Country of birth & $\begin{array}{l}\text { standardized } \\
\text { options }\end{array}$ & $\begin{array}{l}\text { Swiss Federal Statistical Office: ISO code of the } \\
\text { country of origin }\end{array}$ & Mandatory & $\begin{array}{l}\text { Country of birth of } \\
\text { the patient }\end{array}$ \\
\hline General paediatrics & Place of birth (CH) & number & Postal code (PLZ/NPA) & Mandatory & $\begin{array}{l}\text { Municipality of birth } \\
\text { of the patient if in } \\
\text { Switzerland, coded } \\
\text { by postal codes } \\
\text { (PLZ/NPA). }\end{array}$ \\
\hline General paediatrics & Patient administrative gender & $\begin{array}{l}\text { standardized } \\
\text { options }\end{array}$ & $\begin{array}{l}\text { Male } \\
\text { Female } \\
\text { Other }\end{array}$ & Mandatory & \\
\hline General paediatrics & Address (postal code) & number & Postal code (PLZ/NPA) & Mandatory & $\begin{array}{l}\text { Current address of } \\
\text { the patient, coded by } \\
\text { postal codes } \\
\text { (PLZ/NPA). Exact } \\
\text { address should also } \\
\text { be recorded }\end{array}$ \\
\hline General paediatrics & Nationality & $\begin{array}{l}\text { standardized } \\
\text { options }\end{array}$ & $\begin{array}{l}\text { Swiss Federal Statistical Office: ISO code of the } \\
\text { country of origin }\end{array}$ & Mandatory & $\begin{array}{l}\text { Current nationality of } \\
\text { the patient }\end{array}$ \\
\hline General paediatrics & Date of immigration & date & YYYY-MM-DD & Mandatory & $\begin{array}{l}\text { Date of first } \\
\text { immigration to } \\
\text { Switzerland if born } \\
\text { abroad }\end{array}$ \\
\hline
\end{tabular}




\begin{tabular}{|c|c|c|c|c|c|}
\hline Module(s) & Common Data Element & Format & Standardized response options & Importance & $\begin{array}{l}\text { Comment / } \\
\text { Description }\end{array}$ \\
\hline Infectious diseases & If immigrant: Type of residency permit & $\begin{array}{l}\text { standardized } \\
\text { options }\end{array}$ & $\begin{array}{l}\text { B } \\
\text { C } \\
\text { G } \\
\text { L } \\
\text { F } \\
\text { N } \\
\text { S } \\
\text { undocumented }\end{array}$ & Optional & \\
\hline Metabolic diseases & Ethnicity of the mother & $\begin{array}{l}\text { standardized } \\
\text { options }\end{array}$ & See comments & Optional & $\begin{array}{l}\text { Standard } \\
\text { classification to be } \\
\text { defined }\end{array}$ \\
\hline Metabolic diseases & Ethnicity of the father & $\begin{array}{l}\text { standardized } \\
\text { options }\end{array}$ & See comments & Optional & $\begin{array}{l}\text { Standard } \\
\text { classification to be } \\
\text { defined }\end{array}$ \\
\hline $\begin{array}{l}\text { Rheumatology } \\
\text { Pulmonology }\end{array}$ & Ethnicity of the patient & $\begin{array}{l}\text { standardized } \\
\text { options }\end{array}$ & See comments & $\begin{array}{l}\text { Optional } \\
\text { Recommende } \\
\text { d }\end{array}$ & $\begin{array}{l}\text { Standard } \\
\text { classification to be } \\
\text { defined. Optional for } \\
\text { rheumatology, } \\
\text { recommended for } \\
\text { pulmonology. }\end{array}$ \\
\hline \multicolumn{6}{|c|}{ Domain: Medical history } \\
\hline General paediatrics & Reason for consultation / for admission & free text & & Mandatory & $\begin{array}{l}\text { Main reason for } \\
\text { consultation or for } \\
\text { admission. Standard } \\
\text { classification not } \\
\text { defined. }\end{array}$ \\
\hline General paediatrics & Current medications: Drug name & $\begin{array}{l}\text { standardized } \\
\text { options }\end{array}$ & International non-proprietary name & Mandatory & $\begin{array}{l}\text { Name of the drug(s) } \\
\text { received as inpatient }\end{array}$ \\
\hline General paediatrics & Current medications: Route of administration & $\begin{array}{l}\text { standardized } \\
\text { options }\end{array}$ & $\begin{array}{l}\text { Oral } \\
\text { Intravenous } \\
\text { Subcutaneous } \\
\text { Intramuscular } \\
\text { Intrathecal } \\
\text { Rectal } \\
\text { Inhalation } \\
\text { Cutaneous } \\
\text { Ocular } \\
\text { Nasal } \\
\text { Otic } \\
\text { Other }\end{array}$ & Mandatory & \\
\hline General paediatrics & Current medications: Frequency of administration & number & & Mandatory & $\begin{array}{l}\text { Number of } \\
\text { administrations per } \\
24 \text { hours }\end{array}$ \\
\hline
\end{tabular}




\section{Use of complementary medicine}

General paediatics

General paediatrics

General paediatrics

General paediatrics

General paediatrics

\section{General paediatrics}

General paediatrics

General paediatrics

General paediatrics

General paediatrics

General paediatrics

General paediatrics

General paediatrics

General paediatrics

\section{Endocrinology}

Endocrinology

Endocrinology

\begin{tabular}{|l|}
\hline Birth weight \\
\hline Birth length \\
\hline Birth's head circumference \\
\hline Delivery mode
\end{tabular}

\begin{tabular}{|l}
\hline Delivery mode \\
\hline Gestational age
\end{tabular}

Gestational age

\begin{tabular}{|l|}
\hline Apgar score $1 \mathrm{~min}$ \\
\hline Apgar score $5 \mathrm{~min}$
\end{tabular}

Apgar score $10 \mathrm{~min}$

Mother's year of birth

Father's year of birth

\section{Year(s) of birth of sibling(s)}

Drug allergies

Documented food allergies

\section{Age at menarche}

Age at thelarche

\section{standardized}

options

Stan

response options

\begin{tabular}{|l|l|}
\hline Importance \\
\hline
\end{tabular}

yes/no

\begin{tabular}{|c|c|}
\hline number & \\
\hline number & \\
\hline number & \\
\hline $\begin{array}{l}\text { standardized } \\
\text { options }\end{array}$ & $\begin{array}{l}\text { Caesarean section } \\
\text { Instrumental vaginal delivery } \\
\text { Spontaneous vaginal delivery }\end{array}$ \\
\hline
\end{tabular}

\begin{tabular}{|l|l|}
\hline number & \\
\hline number & \\
\hline
\end{tabular}

\begin{tabular}{l|l|l}
\hline number &
\end{tabular}

\begin{tabular}{|l|l}
\hline number & \\
\hline number & Rec
\end{tabular}

number

number

number

standardized

options

\begin{tabular}{|c|c|}
\hline $\begin{array}{l}\text { standardized } \\
\text { options }\end{array}$ & International Nonproprietary Name of drug \\
\hline yes/no & \\
\hline number & \\
\hline number & \\
\hline number & \\
\hline
\end{tabular}

International Nonproprietary Name of drug
Dose given at each

administration of the drug

Mandatory $\quad$ List of possible units

to be defined

\begin{tabular}{l|l} 
Optional & Patient treated with
\end{tabular}

complementary

medicine at home or

in hospital

\begin{tabular}{|l|l|} 
Mandatory & Weight at birth in $\mathrm{kg}$
\end{tabular}

\begin{tabular}{l|l} 
Mandatory & Length at birth in $\mathrm{cm}$ \\
\hline
\end{tabular}

Mandatory $\quad$ Head circumference

\begin{tabular}{l|l} 
& at birth in $\mathrm{cm}$
\end{tabular}

\begin{tabular}{|l|l} 
Birth delivery mode &
\end{tabular}

\begin{tabular}{l|l} 
Mandatory & Post-menstrual age
\end{tabular}

at birth in week and

at birth in
days

Recommende Apgar score $1 \mathrm{~min}$

\begin{tabular}{l|l} 
d & after birth \\
\hline
\end{tabular}

Recommende Apgar score 5 min

after birth

Recommende $\quad$ Apgar score $10 \mathrm{~min}$

\begin{tabular}{l|l}
$\mathrm{d}$ & after birth
\end{tabular}

Mandatory $\quad$ Year of birth of the

\begin{tabular}{l|l} 
& mother \\
\hline Mandatory & Year of birth of the
\end{tabular}

father

\begin{tabular}{l|l} 
Mandatory & Year of birth of
\end{tabular}

sibling(s) if any

$\begin{array}{ll}\text { Mandatory } & \text { Known drug allergies }\end{array}$

\begin{tabular}{l|l} 
Mandatory & Presence of any \\
& documented food
\end{tabular}

documented food

\begin{tabular}{l|l} 
& allergy \\
Mandatory & Age at menarche in
\end{tabular}

\begin{tabular}{l|l} 
Age at thelarche in \\
years
\end{tabular}

\begin{tabular}{l|l} 
& years \\
\hline Mandatory & Age at pubarche in
\end{tabular}

years 


\begin{tabular}{|c|c|c|c|c|c|}
\hline Module(s) & Common Data Element & Format & Standardized response options & Importance & $\begin{array}{l}\text { Comment / } \\
\text { Description }\end{array}$ \\
\hline Endocrinology & Single/Multiple birth & number & & $\begin{array}{l}\text { Recommende } \\
\text { d }\end{array}$ & $\begin{array}{l}\text { Number of children } \\
\text { born from the same } \\
\text { pregnancy as the } \\
\text { patient's }\end{array}$ \\
\hline Endocrinology & Neonatal hypoglycaemia & $\begin{array}{l}\text { standardized } \\
\text { options }\end{array}$ & $\begin{array}{l}\text { No } \\
\text { Yes, confirmed } \\
\text { Yes, reported by patient/family }\end{array}$ & $\begin{array}{l}\text { Recommende } \\
d\end{array}$ & $\begin{array}{l}\text { History of } \\
\text { hypoglycaemia in the } \\
\text { neonatal period }\end{array}$ \\
\hline Endocrinology & Neonatal hyperbilirubinemia & $\begin{array}{l}\text { standardized } \\
\text { options }\end{array}$ & $\begin{array}{l}\text { No } \\
\text { Yes, confirmed } \\
\text { Yes, reported by patient/family }\end{array}$ & $\begin{array}{l}\text { Recommende } \\
\text { d }\end{array}$ & $\begin{array}{l}\text { History of } \\
\text { hyperbilirubinemia in } \\
\text { the neonatal period } \\
\text { (only } \\
\text { hyperbilirubinemia } \\
\text { treated with } \\
\text { phototherapy) }\end{array}$ \\
\hline $\begin{array}{l}\text { Endocrinology } \\
\text { Nephrology }\end{array}$ & Mother's height & number & & Mandatory & $\begin{array}{l}\text { Height of the mother } \\
\text { in } \mathrm{cm}\end{array}$ \\
\hline $\begin{array}{l}\text { Endocrinology } \\
\text { Nephrology }\end{array}$ & Father's height & number & & Mandatory & $\begin{array}{l}\text { Height of the father } \\
\text { in } \mathrm{cm}\end{array}$ \\
\hline Endocrinology & Mother's age at menarche & number & & Mandatory & $\begin{array}{l}\text { Age of the mother at } \\
\text { menarche in years }\end{array}$ \\
\hline Endocrinology & Father's puberty & $\begin{array}{l}\text { standardized } \\
\text { options }\end{array}$ & $\begin{array}{l}\text { Normal } \\
\text { Early } \\
\text { Late }\end{array}$ & Mandatory & \\
\hline Endocrinology & Diabetes in first degree relatives & $\begin{array}{l}\text { standardized } \\
\text { options }\end{array}$ & $\begin{array}{l}\text { No } \\
\text { Yes, Type } 1 \\
\text { Yes, Type } 2 \\
\text { Yes, Monogenic } \\
\text { Unknown }\end{array}$ & Mandatory & $\begin{array}{l}\text { Any type of diabetes } \\
\text { in a first degree } \\
\text { relative }\end{array}$ \\
\hline Endocrinology & Thyroid disorder in first degree relative & yes/no & & Mandatory & $\begin{array}{l}\text { Presence of thyroid } \\
\text { disorder in a first } \\
\text { degree relative }\end{array}$ \\
\hline Endocrinology & Other auto-immune disorders in first degree relative & yes/no & & $\begin{array}{l}\text { Recommende } \\
\text { d }\end{array}$ & $\begin{array}{l}\text { Presence of auto- } \\
\text { immune disorder in a } \\
\text { first degree relative. } \\
\text { With added box for } \\
\text { free text to specify } \\
\text { the disease. }\end{array}$ \\
\hline Endocrinology & Other endocrinopathy in first degree relative & yes/no & & Mandatory & $\begin{array}{l}\text { Presence of } \\
\text { endocrinopathy in a } \\
\text { first degree relative. } \\
\text { With added box for } \\
\text { free text to specify } \\
\text { the disease. }\end{array}$ \\
\hline
\end{tabular}




\begin{tabular}{|c|c|c|c|c|c|}
\hline Module(s) & Common Data Element & Format & Standardized response options & Importance & $\begin{array}{l}\text { Comment / } \\
\text { Description }\end{array}$ \\
\hline Endocrinology & Fertility problems in first degree relative & yes/no & & $\begin{array}{l}\text { Recommende } \\
d\end{array}$ & $\begin{array}{l}\text { Presence of fertility } \\
\text { problems in first } \\
\text { degree relatives. } \\
\text { With added box for } \\
\text { free text to specify } \\
\text { the disease. }\end{array}$ \\
\hline Endocrinology & Severe hypoglycaemia (requiring assistance OR coma) & number & & Mandatory & $\begin{array}{l}\text { Number of events } \\
\text { since last visit }\end{array}$ \\
\hline Endocrinology & Mild hypoglycaemia (BG $<3.9 \mathrm{mmol} / \mathrm{I}$ ) & number & & Mandatory & $\begin{array}{l}\text { Number of events } \\
\text { per month }\end{array}$ \\
\hline Endocrinology & Ketoacidosis & $\begin{array}{l}\text { standardized } \\
\text { options }\end{array}$ & $\begin{array}{l}\text { No } \\
\text { Yes, managed ambulatorily } \\
\text { Yes, with hospitalization }\end{array}$ & Mandatory & $\begin{array}{l}\text { History of } \\
\text { ketoacidosis }\end{array}$ \\
\hline Endocrinology & Diagnostic of obesity in first degree relative & yes/no & & $\begin{array}{l}\text { Recommende } \\
d\end{array}$ & $\begin{array}{l}\text { Diagnostic of obesity } \\
\text { in a first degree } \\
\text { relative }\end{array}$ \\
\hline Gastroenterology & Nutrition habits & $\begin{array}{l}\text { standardized } \\
\text { options }\end{array}$ & $\begin{array}{l}\text { No specific diet } \\
\text { Vegetarian } \\
\text { Vegan } \\
\text { Other } \\
\end{array}$ & $\begin{array}{l}\text { Recommende } \\
d\end{array}$ & $\begin{array}{l}\text { Nutrition habits of } \\
\text { the patient }\end{array}$ \\
\hline $\begin{array}{l}\text { Gastroenterology } \\
\text { Metabolic diseases }\end{array}$ & Route of feeding & $\begin{array}{l}\text { standardized } \\
\text { options }\end{array}$ & $\begin{array}{l}\text { Oral } \\
\text { Gastrostomy } \\
\text { Naso/orogastric tube } \\
\text { Intravenous } \\
\text { Other }\end{array}$ & Mandatory & $\begin{array}{l}\text { The route(s) by which } \\
\text { the patient is fed }\end{array}$ \\
\hline Allergy/Immunology & History of rhinoconjonctivitis & $\begin{array}{l}\text { standardized } \\
\text { options }\end{array}$ & $\begin{array}{l}\text { Yes, reported } \\
\text { Yes, documented } \\
\text { No }\end{array}$ & Mandatory & \\
\hline Allergy/Immunology & History of atopic dermatitis & $\begin{array}{l}\text { standardized } \\
\text { options }\end{array}$ & $\begin{array}{l}\text { Yes, reported } \\
\text { Yes, documented } \\
\text { No }\end{array}$ & Mandatory & \\
\hline Allergy/Immunology & History of wheezing & $\begin{array}{l}\text { standardized } \\
\text { options }\end{array}$ & $\begin{array}{l}\text { Yes, reported } \\
\text { Yes, documented } \\
\text { No }\end{array}$ & Mandatory & \\
\hline Allergy/Immunology & History of asthma & $\begin{array}{l}\text { standardized } \\
\text { options }\end{array}$ & $\begin{array}{l}\text { Yes, reported } \\
\text { Yes, documented } \\
\text { No }\end{array}$ & Mandatory & \\
\hline Allergy/Immunology & Respiratory support during first hours of life & $\begin{array}{l}\text { standardized } \\
\text { options }\end{array}$ & $\begin{array}{l}\text { Yes, reported } \\
\text { Yes, documented } \\
\text { No }\end{array}$ & $\begin{array}{l}\text { Recommende } \\
d\end{array}$ & $\begin{array}{l}\text { Presence of any kind } \\
\text { of respiratory } \\
\text { support (non- } \\
\text { invasive and invasive } \\
\text { ventilation) during } \\
\text { first hours of life }\end{array}$ \\
\hline
\end{tabular}




\section{Chronic diarrhea} options

Allergy/Immunology Number of hospitalisations for IV antibiotherapy in life

Allergy/Immunology Maximal number of otitis media in one year

Allergy/Immunology

Allergy/Immunology

Allergy/Immunology

Allergy/Immunology

Allergy/Immunology

\section{Number of pneumonias in life}

Number of sinusitis in life

Number of meningitis in life

Family history of atopic diseases

Allergy/Immunology

Family history of immunodeficiency

Allergy/Immunology

Allergy/Immunology

Allergy/Immunology

Gastroenterology

Allergy/Immunology

\section{Allergy/Immunology}

Allergy/Immunology

\section{Family history of auto-immune disease}

yes/no

Yes, reported

Yes, documented

number

number

(20)

\begin{tabular}{|l} 
\\
\hline Infectious diseases \\
\hline Infectious diseases \\
\hline Infectious diseases
\end{tabular}

Family history of angioedema

Documented food allergy by oral food challenge

Hymenoptera venom allergies

History of anaphylaxis

Autoimmune or inflammatory diseases in the patient

\section{History of fever $\left(>38^{\circ} \mathrm{C}\right)$}

If history of fever: Number of days with fever

History of cough

number

number

number

yes/no

yes/no

yes/no

yes/no

yes/no

options

Yes, reported

Yes, documented

No

Yes, reported
Yes, documented

No

options

yes/no

$\mid$

\begin{tabular}{|l|}
\hline \\
\hline
\end{tabular}



Recommende

\begin{tabular}{|c|c|}
\hline d & $\begin{array}{l}\text { administered during } \\
\text { first hours of life }\end{array}$ \\
\hline \multicolumn{2}{|l|}{ Mandatory } \\
\hline Mandatory & \\
\hline Mandatory & \\
\hline \multicolumn{2}{|l|}{ Mandatory } \\
\hline \multicolumn{2}{|l|}{ Mandatory } \\
\hline \multicolumn{2}{|l|}{ Mandatory } \\
\hline Mandatory & $\begin{array}{l}\text { Presence of atopic } \\
\text { diseases in a first } \\
\text { degree relative }\end{array}$ \\
\hline Mandatory & $\begin{array}{l}\text { Presence of } \\
\text { immunodeficiency in } \\
\text { a first degree relative }\end{array}$ \\
\hline Mandatory & $\begin{array}{l}\text { Presence of auto- } \\
\text { immune disease in a } \\
\text { first degree relative }\end{array}$ \\
\hline Mandatory & $\begin{array}{l}\text { Presence of } \\
\text { angioedema in a first } \\
\text { degree relative }\end{array}$ \\
\hline Mandatory & $\begin{array}{l}\text { Presence of any } \\
\text { documented food } \\
\text { allergy (diagnosed by } \\
\text { physician) }\end{array}$ \\
\hline Mandatory & $\begin{array}{l}\text { Known documented } \\
\text { hymenopter allergies }\end{array}$ \\
\hline Mandatory & $\begin{array}{l}\text { History of } \\
\text { anaphylaxis }\end{array}$ \\
\hline Mandatory & $\begin{array}{l}\text { Classification for type } \\
\text { of autoimmunity } \\
\text { (organ specific or } \\
\text { systemic) and } \\
\text { organ(s) involved will } \\
\text { be further defined. }\end{array}$ \\
\hline \multicolumn{2}{|l|}{ Mandatory } \\
\hline \multicolumn{2}{|l|}{ Mandatory } \\
\hline Mandatory & \\
\hline
\end{tabular}

Published under the copyright license "Attribution-NonCommercial-ShareAlike 4.0 International (CC BY-NC-SA 4.0)".

No commercial reuse without permission. See https://smw.ch/permissions. 


\begin{tabular}{|c|c|c|c|c|c|}
\hline Module(s) & Common Data Element & Format & Standardized response options & Importance & $\begin{array}{l}\text { Comment / } \\
\text { Description }\end{array}$ \\
\hline Infectious diseases & History of running nose & yes/no & & Mandatory & \\
\hline Infectious diseases & History of diarrhea & yes/no & & Mandatory & \\
\hline Infectious diseases & History of vomiting & yes/no & & Mandatory & \\
\hline Infectious diseases & History of headache & yes/no & & Mandatory & \\
\hline Infectious diseases & Travel history in the last 6 months & $\begin{array}{l}\text { standardized } \\
\text { options }\end{array}$ & $\begin{array}{l}\text { Swiss Federal Statistical Office: ISO code of the } \\
\text { country of origin (selection of }>1 \text { possible) }\end{array}$ & Mandatory & $\begin{array}{l}\text { Country(ies) visited in } \\
\text { the last } 6 \text { months }\end{array}$ \\
\hline Infectious diseases & History of tick bite & yes/no & & $\begin{array}{l}\text { Recommende } \\
\text { d }\end{array}$ & \\
\hline Infectious diseases & If history of tick bite: Month of tick bite & date & YYYY-MM & $\begin{array}{l}\text { Recommende } \\
\text { d }\end{array}$ & \\
\hline Infectious diseases & History of contact with animals & yes/no & $\begin{array}{l}\text { No } \\
\text { Yes }\end{array}$ & Optional & $\begin{array}{l}\text { Standard animal list } \\
\text { to be defined }\end{array}$ \\
\hline Infectious diseases & Pertussis immunization during pregnancy & yes/no & & Mandatory & $\begin{array}{l}\text { For patients under } 6 \\
\text { months of age }\end{array}$ \\
\hline Infectious diseases & Influenza immunization during pregnancy & yes/no & & Mandatory & $\begin{array}{l}\text { For patients under } 6 \\
\text { months of age }\end{array}$ \\
\hline Infectious diseases & Prolonged rupture of membranes & yes/no & & Mandatory & $\begin{array}{l}\text { For patients under } 1 \\
\text { month of age. } \\
\text { Prolonged rupture } \\
\text { defined as longer } \\
\text { than } 18 \mathrm{~h}\end{array}$ \\
\hline Infectious diseases & Maternal GBS colonization & $\begin{array}{l}\text { standardized } \\
\text { options }\end{array}$ & $\begin{array}{l}\text { Positive } \\
\text { Negative } \\
\text { Unknown }\end{array}$ & Mandatory & $\begin{array}{l}\text { For patients under } 1 \\
\text { month of age }\end{array}$ \\
\hline Infectious diseases & Maternal HIV serology & $\begin{array}{l}\text { standardized } \\
\text { options }\end{array}$ & $\begin{array}{l}\text { Positive } \\
\text { Negative } \\
\text { Unknown }\end{array}$ & Mandatory & $\begin{array}{l}\text { For patients under } 1 \\
\text { month of age }\end{array}$ \\
\hline Infectious diseases & Maternal HBsAg & $\begin{array}{l}\text { standardized } \\
\text { options }\end{array}$ & $\begin{array}{l}\text { Positive } \\
\text { Negative } \\
\text { Unknown }\end{array}$ & Mandatory & $\begin{array}{l}\text { For patients under } 1 \\
\text { month of age }\end{array}$ \\
\hline Infectious diseases & Maternal HBsAb & $\begin{array}{l}\text { standardized } \\
\text { options }\end{array}$ & $\begin{array}{l}\text { Positive } \\
\text { Negative } \\
\text { Unknown }\end{array}$ & Mandatory & $\begin{array}{l}\text { For patients under } 1 \\
\text { month of age }\end{array}$ \\
\hline Infectious diseases & Maternal HBcAb & $\begin{array}{l}\text { standardized } \\
\text { options }\end{array}$ & $\begin{array}{l}\text { Positive } \\
\text { Negative } \\
\text { Unknown }\end{array}$ & Mandatory & $\begin{array}{l}\text { For patients under } 1 \\
\text { month of age }\end{array}$ \\
\hline Infectious diseases & Maternal HBeAg & $\begin{array}{l}\text { standardized } \\
\text { options }\end{array}$ & $\begin{array}{l}\text { Positive } \\
\text { Negative } \\
\text { Unknown }\end{array}$ & Mandatory & $\begin{array}{l}\text { For patients under } 1 \\
\text { month of age }\end{array}$ \\
\hline
\end{tabular}




\begin{tabular}{|c|c|c|c|c|c|}
\hline Module(s) & Common Data Element & Format & Standardized response options & Importance & $\begin{array}{l}\text { Comment / } \\
\text { Description }\end{array}$ \\
\hline Infectious diseases & Maternal HCV serology & $\begin{array}{l}\text { standardized } \\
\text { options }\end{array}$ & $\begin{array}{l}\text { Positive } \\
\text { Negative } \\
\text { Unknown }\end{array}$ & Mandatory & $\begin{array}{l}\text { For patients under } 1 \\
\text { month of age }\end{array}$ \\
\hline Infectious diseases & Maternal CMV serology (IgG / IgM) & $\begin{array}{l}\text { standardized } \\
\text { options }\end{array}$ & $\begin{array}{l}\text { Positive } \\
\text { Negative } \\
\text { Unknown }\end{array}$ & Optional & $\begin{array}{l}\text { For patients under } 1 \\
\text { month of age }\end{array}$ \\
\hline Infectious diseases & Maternal syphilis serology & $\begin{array}{l}\text { standardized } \\
\text { options }\end{array}$ & $\begin{array}{l}\text { Positive } \\
\text { Negative } \\
\text { Unknown }\end{array}$ & Mandatory & $\begin{array}{l}\text { For patients under } 1 \\
\text { month of age }\end{array}$ \\
\hline Infectious diseases & Maternal rubella serology & $\begin{array}{l}\text { standardized } \\
\text { options }\end{array}$ & $\begin{array}{l}\text { Positive } \\
\text { Negative } \\
\text { Unknown }\end{array}$ & Mandatory & $\begin{array}{l}\text { For patients under } 1 \\
\text { month of age }\end{array}$ \\
\hline Infectious diseases & Maternal toxoplasmosis serology & $\begin{array}{l}\text { standardized } \\
\text { options }\end{array}$ & $\begin{array}{l}\text { Positive } \\
\text { Negative } \\
\text { Unknown }\end{array}$ & optional & $\begin{array}{l}\text { For patients under } 1 \\
\text { month of age }\end{array}$ \\
\hline Infectious diseases & Maternal Chagas serology & $\begin{array}{l}\text { standardized } \\
\text { options }\end{array}$ & $\begin{array}{l}\text { Positive } \\
\text { Negative } \\
\text { Unknown }\end{array}$ & Mandatory & $\begin{array}{l}\text { For patients under } 1 \\
\text { month of age }\end{array}$ \\
\hline Metabolic diseases & Self-monitoring of blood glucose & yes/no & & Optional & $\begin{array}{l}\text { Regular self- } \\
\text { monitoring of blood } \\
\text { glucose done at } \\
\text { home }\end{array}$ \\
\hline Metabolic diseases & Self-monitoring of ketone bodies & yes/no & & Optional & $\begin{array}{l}\text { Regular self- } \\
\text { monitoring of ketone } \\
\text { bodies done at home }\end{array}$ \\
\hline Nephrology & Prenatal ultrasound & $\begin{array}{l}\text { standardized } \\
\text { option }\end{array}$ & $\begin{array}{l}\text { Normal } \\
\text { An-/Oligohydramnios } \\
\text { Polyhydramnios } \\
\text { Megacystis } \\
\text { Megaureter } \\
\text { Bilateral renal pelvis dilatation }>10 \mathrm{~mm} \\
\text { Bilateral renal pelvis dilatation }<10 \mathrm{~mm} \\
\text { Unilateral renal pelvis dilatation }>10 \mathrm{~mm} \\
\text { Renal cysts } \\
\text { Renal agenesis or ectopia } \\
\text { Multicystic-dysplastic kidney and bladder extrophy }\end{array}$ & Mandatory & \\
\hline Nephrology & Family history of renal disease (1st-2nd degree) & yes/no & & Mandatory & \\
\hline Neurology & Seizure type (ILEA 2017 Classification of Seizures) & $\begin{array}{l}\text { standardized } \\
\text { options }\end{array}$ & $\begin{array}{l}\text { Focal Onset } \\
\text { Generalized Onset } \\
\text { Unknown Onset } \\
\text { Unclassified }\end{array}$ & $\begin{array}{l}\text { Recommende } \\
d\end{array}$ & $\begin{array}{l}\text { Seizure type } \\
\text { according to the ILEA } \\
2017 \text { classification of } \\
\text { seizures }\end{array}$ \\
\hline Neurology & Family history of neurological diseases & yes/no & & $\begin{array}{l}\text { Recommende } \\
d\end{array}$ & $\begin{array}{l}\text { Family history of any } \\
\text { type of neurological } \\
\text { diseases }\end{array}$ \\
\hline
\end{tabular}




\begin{tabular}{|c|c|c|c|c|c|}
\hline Module(s) & Common Data Element & Format & Standardized response options & Importance & $\begin{array}{l}\text { Comment / } \\
\text { Description }\end{array}$ \\
\hline Pulmonology & Cough & $\begin{array}{l}\text { standardized } \\
\text { options }\end{array}$ & $\begin{array}{l}\text { No } \\
\text { Yes, acute and dry } \\
\text { Yes, acute and wet } \\
\text { Yes, chronic and dry } \\
\text { Yes, chronic and wet }\end{array}$ & $\begin{array}{l}\text { Recommende } \\
d\end{array}$ & $\begin{array}{l}\text { Cut-off for } \\
\text { acute/chronic } 4 \\
\text { weeks }\end{array}$ \\
\hline Rheumatology & Recurrent fever & yes/no & & Mandatory & $\begin{array}{l}\text { History of recurrent } \\
\text { fever }\end{array}$ \\
\hline Rheumatology & History of uveitis & yes/no & & Mandatory & $\begin{array}{l}\text { Presence of active } \\
\text { uveitis }\end{array}$ \\
\hline Rheumatology & History of inflammatory skin disease & yes/no & & Mandatory & $\begin{array}{l}\text { Presence of skin } \\
\text { involvement }\end{array}$ \\
\hline Rheumatology & Family history of inflammatory rheumatic disease & $\begin{array}{l}\text { standardized } \\
\text { options }\end{array}$ & $\begin{array}{l}\text { No } \\
\text { Yes, without spondyloarthropathy } \\
\text { Yes, with spondyloarthropathy }\end{array}$ & Mandatory & $\begin{array}{l}\text { Presence of any } \\
\text { rheumatic disease in } \\
\text { the family }\end{array}$ \\
\hline Rheumatology & Family history of inflammatory skin disease & $\begin{array}{l}\text { standardized } \\
\text { options }\end{array}$ & $\begin{array}{l}\text { No } \\
\text { Yes, without psoariasis } \\
\text { Yes, with psoriasis }\end{array}$ & Mandatory & $\begin{array}{l}\text { Presence of any skin } \\
\text { disease in the family }\end{array}$ \\
\hline Rheumatology & Family history of chronic intestinal diseases & yes/no & & Mandatory & $\begin{array}{l}\text { Presence of any } \\
\text { chronic intestinal } \\
\text { disease in the family }\end{array}$ \\
\hline Rheumatology & Family history of recurrent fever & yes/no & & Mandatory & $\begin{array}{l}\text { Presence of recurrent } \\
\text { fever in the family }\end{array}$ \\
\hline \multicolumn{6}{|c|}{ Domain: Physical examination } \\
\hline General paediatrics & Heart rate & number & & Mandatory & $\begin{array}{l}\text { Heart rate in beats } \\
\text { per minute }\end{array}$ \\
\hline General paediatrics & Systolic blood pressure & number & & Mandatory & $\begin{array}{l}\text { Value of the systolic } \\
\text { blood pressure in } \\
\mathrm{mmHg}\end{array}$ \\
\hline General paediatrics & Diastolic blood pressure & number & & Mandatory & $\begin{array}{l}\text { Value of the diastolic } \\
\text { blood pressure in } \\
\mathrm{mmHg}\end{array}$ \\
\hline General paediatrics & Respiratory rate & number & & Mandatory & $\begin{array}{l}\text { Respiratory rate in } \\
\text { breaths per minute }\end{array}$ \\
\hline General paediatrics & Oxygen saturation & number & & Mandatory & $\begin{array}{l}\text { Measured oxygen } \\
\text { saturation in \% }\end{array}$ \\
\hline General paediatrics & Temperature & number & & Mandatory & $\begin{array}{l}\text { Measured } \\
\text { temperature of the } \\
\text { patient in Celsius } \\
\text { degrees }\end{array}$ \\
\hline General paediatrics & Weight & number & & Mandatory & $\begin{array}{l}\text { Measured weight of } \\
\text { the patient in } \mathrm{kg}\end{array}$ \\
\hline
\end{tabular}




\begin{tabular}{|c|c|c|c|c|c|}
\hline Module(s) & Common Data Element & Format & Standardized response options & Importance & $\begin{array}{l}\text { Comment / } \\
\text { Description }\end{array}$ \\
\hline General paediatrics & Height & number & & Mandatory & $\begin{array}{l}\text { Measured height of } \\
\text { the patient in } \mathrm{cm}\end{array}$ \\
\hline General paediatrics & Head circumference & number & & Mandatory & $\begin{array}{l}\text { Measured head } \\
\text { circumference of the } \\
\text { patient in } \mathrm{cm}\end{array}$ \\
\hline Endocrinology & Sitting height & number & & $\begin{array}{l}\text { Recommende } \\
\text { d }\end{array}$ & $\begin{array}{l}\text { Sitting height } \\
\text { measured sitting with } \\
\text { straight back in in } \mathrm{cm}\end{array}$ \\
\hline Endocrinology & Arm span & number & & $\begin{array}{l}\text { Recommende } \\
\text { d }\end{array}$ & $\begin{array}{l}\text { Arm span: arms } \\
\text { streched horizontally, } \\
\text { measurement from } \\
\text { fingertip to fingertip } \\
\text { in } \mathrm{cm}\end{array}$ \\
\hline Endocrinology & Waist circumference & number & & $\begin{array}{l}\text { Recommende } \\
d\end{array}$ & $\ln \mathrm{cm}$ \\
\hline Endocrinology & Hip circumference & number & & $\begin{array}{l}\text { Recommende } \\
d\end{array}$ & In cm \\
\hline Endocrinology & Goiter & yes/no & & $\begin{array}{l}\text { Recommende } \\
d\end{array}$ & Presence of goiter \\
\hline Endocrinology & Gynecomastia & $\begin{array}{l}\text { standardized } \\
\text { options }\end{array}$ & $\begin{array}{l}\text { No } \\
\text { Yes, unilateral } \\
\text { Yes, bilateral }\end{array}$ & $\begin{array}{l}\text { Recommende } \\
\text { d }\end{array}$ & $\begin{array}{l}\text { Presence of } \\
\text { gynecomastia }\end{array}$ \\
\hline $\begin{array}{l}\text { Endocrinology } \\
\text { Metabolic diseases }\end{array}$ & Dysmorphic signs & yes/no & & $\begin{array}{l}\text { Recommende } \\
\text { d }\end{array}$ & $\begin{array}{l}\text { Presence of } \\
\text { dysmorphic features. } \\
\text { If answer is yes, } \\
\text { specification with } \\
\text { standardized } \\
\text { classification to be } \\
\text { defined. }\end{array}$ \\
\hline Endocrinology & Cryptorchidism & $\begin{array}{l}\text { standardized } \\
\text { options }\end{array}$ & \begin{tabular}{|l|} 
No \\
Yes, unilateral \\
Yes, bilateral \\
\end{tabular} & Mandatory & $\begin{array}{l}\text { Presence of } \\
\text { cryptorchidism }\end{array}$ \\
\hline Endocrinology & Insulin injection site & $\begin{array}{l}\text { standardized } \\
\text { options }\end{array}$ & $\begin{array}{l}\text { Normal } \\
\text { Abnormal, lipoatrophy } \\
\text { Abnormal, lipohypertrophy }\end{array}$ & Optional & $\begin{array}{l}\text { Inspection of insulin } \\
\text { delivery sites }\end{array}$ \\
\hline Endocrinology & Retinopathy screening & normal/abnormal & & Optional & \\
\hline Endocrinology & Neuropathy screening performed & $\begin{array}{l}\text { standardized } \\
\text { options }\end{array}$ & $\begin{array}{l}\text { No } \\
\text { Yes, vibration } \\
\text { Yes, monofilament }\end{array}$ & Optional & \\
\hline Endocrinology & Testis volume right side & number & & Mandatory & $\begin{array}{l}\text { Volume of right testis } \\
\text { in } \mathrm{ml}\end{array}$ \\
\hline Endocrinology & Testis volume left side & number & & Mandatory & $\begin{array}{l}\text { Volume of left testis } \\
\text { in } \mathrm{ml}\end{array}$ \\
\hline
\end{tabular}




\begin{tabular}{|c|c|c|c|c|c|}
\hline Module(s) & Common Data Element & Format & Standardized response options & Importance & $\begin{array}{l}\text { Comment / } \\
\text { Description }\end{array}$ \\
\hline Endocrinology & Tanner breast stage & number & & Mandatory & \\
\hline Endocrinology & Tanner pubic hair stage & number & & Mandatory & \\
\hline Endocrinology & Tanner axillary hair stage & number & & Mandatory & \\
\hline Endocrinology & Tanner genital stage & number & & $\begin{array}{l}\text { Recommende } \\
\text { d }\end{array}$ & \\
\hline Endocrinology & Breast size & number & & Optional & In cm \\
\hline Endocrinology & Female genital examination & normal/abnormal & & Mandatory & \\
\hline Endocrinology & Penis length & number & & $\begin{array}{l}\text { Recommende } \\
d\end{array}$ & In cm \\
\hline Endocrinology & Chovstek sign & yes/no & & $\begin{array}{l}\text { Recommende } \\
\text { d }\end{array}$ & $\begin{array}{l}\text { Twitching of facial } \\
\text { muscles in response } \\
\text { to tapping over the } \\
\text { area of the facial } \\
\text { nerve }\end{array}$ \\
\hline Endocrinology & Trousseau sign & yes/no & & $\begin{array}{l}\text { Recommende } \\
\text { d }\end{array}$ & $\begin{array}{l}\text { Carpopedal spasm } \\
\text { that results from } \\
\text { ischemia }\end{array}$ \\
\hline Endocrinology & Thyroid nodule & yes/no & & $\begin{array}{l}\text { Recommende } \\
\text { d }\end{array}$ & $\begin{array}{l}\text { Presence of thyroid } \\
\text { nodule }\end{array}$ \\
\hline $\begin{array}{l}\text { Infectious diseases } \\
\text { Metabolic diseases } \\
\text { Rheumatology }\end{array}$ & Hepatomegaly noted at physical examination & yes/no & & Mandatory & \\
\hline $\begin{array}{l}\text { Infectious diseases } \\
\text { Metabolic diseases } \\
\text { Rheumatology }\end{array}$ & Splenomegaly noted at physical examination & yes/no & & Mandatory & \\
\hline Infectious diseases & Meningeal signs noted at physical examination & yes/no & & Mandatory & \\
\hline $\begin{array}{l}\text { Infectious diseases } \\
\text { Rheumatology }\end{array}$ & Skin lesion noted at physical examination & yes/no & & Mandatory & \\
\hline Infectious diseases & Irritability noted during physical examination & yes/no & & Mandatory & \\
\hline $\begin{array}{l}\text { Infectious diseases } \\
\text { Rheumatology }\end{array}$ & Adenopathy noted at physical examination & $\begin{array}{l}\text { standardized } \\
\text { options }\end{array}$ & $\begin{array}{l}\text { No } \\
\text { Yes, localized } \\
\text { Yes, generalized }\end{array}$ & Mandatory & \\
\hline Infectious diseases & Respiratory distress noted at physical examination & yes/no & & Mandatory & \\
\hline Infectious diseases & Conjunctivitis noted at physical examination & yes/no & & Mandatory & \\
\hline Infectious diseases & $\begin{array}{l}\text { Prolonged capillary refill time }(>2 \mathrm{sec}) \text { noted at physical } \\
\text { examination }\end{array}$ & yes/no & & Mandatory & \\
\hline
\end{tabular}


Metabolic diseases

Skin abormalities

Yes, $5-10 \%$

\section{Metabolic diseases}

\section{Abnormal body proportions}

Nephrology

yes/no

Average 24-hour arterial pressure, systolic

Nephrology Average 24-hour arterial pressure, diastolic

Nephrology

Nephrology

Nephrology

Nephrology

Nephrology

Nephrology

Average daytime systolic BP

Average daytime diastolic BP

Average night-time systolic BP

Average night-time diastolic BP

Mean Arterial Pressure (MAP)

.

\begin{tabular}{|l|}
\hline Neurology \\
\hline Pulmonology \\
\hline Pulmonology
\end{tabular}

Blood pressure dipping pattern

Pulmonology

Rheumatology

Rheumatology

\begin{tabular}{|l|}
\hline Walking ability \\
\hline Auscultation
\end{tabular}

yes/no

$\mathrm{Y}$

$\mid$\begin{tabular}{l|l|} 
& number \\
&
\end{tabular}

\begin{tabular}{|l|}
\hline Rheumatology \\
\hline Rheumatology \\
\hline
\end{tabular}

\begin{tabular}{|l|}
\hline Thorax shape \\
\hline Active arthritis \\
\hline Maximal mouth opening \\
\hline Muscle strength
\end{tabular}

\begin{tabular}{|l|l|}
\hline $\begin{array}{l}\text { standardized } \\
\text { options }\end{array}$ & $\begin{array}{l}\text { Community ambulator } \\
\text { Household ambulator } \\
\text { Non-ambulatory }\end{array}$ \\
\hline normal/abnormal & \\
\hline normal/abnormal & \\
\hline yes/no & \\
\hline number & \\
\hline normal/abnormal & \\
\hline
\end{tabular}

Mandatory

Description

Mresence of skin

\begin{tabular}{|c|c|}
\hline Mandatory & $\begin{array}{l}\text { Presence of skin } \\
\text { abnormalities }\end{array}$ \\
\hline $\begin{array}{l}\text { Recommende } \\
\mathrm{d}\end{array}$ & $\begin{array}{l}\text { Presence of } \\
\text { abnormal body } \\
\text { proportions }\end{array}$ \\
\hline Mandatory & In $\mathrm{mmHg}$ \\
\hline Mandatory & In $\mathrm{mmHg}$ \\
\hline Mandatory & In $\mathrm{mmHg}$ \\
\hline Mandatory & In $\mathrm{mmHg}$ \\
\hline Mandatory & In $\mathrm{mmHg}$ \\
\hline Mandatory & In $\mathrm{mmHg}$ \\
\hline Mandatory & $\begin{array}{l}\text { Measured MAP in } \\
\mathrm{mmHg}\end{array}$ \\
\hline Mandatory & $\begin{array}{l}\text { Difference between } \\
\text { daytime mean } \\
\text { systolic pressure and } \\
\text { night-time mean } \\
\text { systolic pressure } \\
\text { expressed as a } \\
\text { percentage of the } \\
\text { day value }\end{array}$ \\
\hline \multicolumn{2}{|l|}{ Mandatory } \\
\hline \multicolumn{2}{|l|}{ Mandatory } \\
\hline Mandatory & $\begin{array}{l}\text { The shape of the } \\
\text { thorax }\end{array}$ \\
\hline Mandatory & $\begin{array}{l}\text { Presence of active } \\
\text { arthritis }\end{array}$ \\
\hline Mandatory & $\begin{array}{l}\text { Number of joints } \\
\text { involved in active } \\
\text { arthritis }\end{array}$ \\
\hline Mandatory & $\begin{array}{l}\text { Maximal mouth } \\
\text { opening in } \mathrm{mm}\end{array}$ \\
\hline $\begin{array}{l}\text { Recommende } \\
\mathrm{d}\end{array}$ & $\begin{array}{l}\text { Overall muscle } \\
\text { strength }\end{array}$ \\
\hline
\end{tabular}


Domain: Clinical scores

\begin{tabular}{|c|c|c|c|c|c|}
\hline General paediatrics & Triage scale (ED), type & $\begin{array}{l}\text { standardized } \\
\text { options }\end{array}$ & $\begin{array}{l}\text { Australasian Triage Scale } \\
\text { Canadian Triage Scale } \\
\text { Other }\end{array}$ & Mandatory & $\begin{array}{l}\text { Name of the triage } \\
\text { scale used }\end{array}$ \\
\hline General paediatrics & Triage scale (ED), value & number & & Mandatory & $\begin{array}{l}\text { Value of the triage } \\
\text { scale }\end{array}$ \\
\hline General paediatrics & AVPU score & $\begin{array}{l}\text { standardized } \\
\text { options }\end{array}$ & $\begin{array}{l}\text { Alert } \\
\text { Voice } \\
\text { Pain } \\
\text { Unresponsive }\end{array}$ & Mandatory & \\
\hline General paediatrics & Glasgow Coma Scale & number & & Mandatory & \\
\hline Cardiology & Modified Ross heart failure classification for children & $\begin{array}{l}\text { standardized } \\
\text { options }\end{array}$ & $\begin{array}{l}\text { Class I } \\
\text { Class II } \\
\text { Class III } \\
\text { Class IV }\end{array}$ & Mandatory & $\begin{array}{l}\text { Class I: } \\
\text { Asymptomatic } \\
\text { Class II: Mild } \\
\text { tachypnea or } \\
\text { diaphoresis with } \\
\text { feeding in infants, } \\
\text { dyspnea on exertion } \\
\text { in older children } \\
\text { Class III: Marked } \\
\text { tachypnea or } \\
\text { diaphoresis with } \\
\text { feeding in infants, } \\
\text { marked dyspnea on } \\
\text { exertion, prolonged } \\
\text { feeding times with } \\
\text { growth failure } \\
\text { Class IV: Symptoms } \\
\text { such as tachypnea, } \\
\text { retractions, grunting } \\
\text { or diaphoresis at rest }\end{array}$ \\
\hline
\end{tabular}




\begin{tabular}{|c|c|c|c|c|c|}
\hline Module(s) & Common Data Element & Format & Standardized response options & Importance & $\begin{array}{l}\text { Comment / } \\
\text { Description }\end{array}$ \\
\hline Cardiology & NYHA classification for adults & $\begin{array}{l}\text { standardized } \\
\text { options }\end{array}$ & $\begin{array}{l}\text { Class I } \\
\text { Class II } \\
\text { Class III } \\
\text { Class IV }\end{array}$ & Mandatory & $\begin{array}{l}\text { Class I: No symptoms } \\
\text { and no limitation in } \\
\text { ordinary physical } \\
\text { activity } \\
\text { Class II: Mild } \\
\text { symptoms (mild } \\
\text { shortness of breath } \\
\text { and/or angina) and } \\
\text { slight limitation } \\
\text { during ordinary } \\
\text { activity. } \\
\text { Class III: Marked } \\
\text { limitation in activity } \\
\text { due to symptoms, } \\
\text { even during less- } \\
\text { than-ordinary } \\
\text { activity. Comfortable } \\
\text { only at rest. } \\
\text { Class IV: Severe } \\
\text { limitations. } \\
\text { Experiences } \\
\text { symptoms even while } \\
\text { at rest. Mostly } \\
\text { bedbound patients. }\end{array}$ \\
\hline Endocrinology & Endocrinology clinical score type & $\begin{array}{l}\text { standardized } \\
\text { options }\end{array}$ & $\begin{array}{l}\text { Crook score } \\
\text { Billewicz score } \\
\text { Ferriman-Gallway score } \\
\text { Prader stage } \\
\text { External genitalia score }\end{array}$ & Optional & Type of score \\
\hline Endocrinology & Endocrinology clinical score result & number & number & Optional & Result of score \\
\hline Gastroenterology & PCDAI & number & & Mandatory & $\begin{array}{l}\text { Paediatric Crohn's } \\
\text { Disease Activity Index }\end{array}$ \\
\hline Gastroenterology & PUCAI & number & & Mandatory & $\begin{array}{l}\text { Paediatric Ulcerative } \\
\text { Colitis Activity Index }\end{array}$ \\
\hline Gastroenterology & PYMS score & number & & Mandatory & $\begin{array}{l}\text { Paediatric Yorkhill } \\
\text { Malnutrition Score }\end{array}$ \\
\hline Gastroenterology & Bristol stool scale & number & & Mandatory & \\
\hline Allergy/Immunology & SCORAD index & number & & Mandatory & $\begin{array}{l}\text { SCORing Atopic } \\
\text { Dermatitis Index }\end{array}$ \\
\hline $\begin{array}{l}\text { Metabolic diseases } \\
\text { Neurology }\end{array}$ & Developmental test: Type & $\begin{array}{l}\text { standardized } \\
\text { options }\end{array}$ & $\begin{array}{l}\text { Bayley II } \\
\text { Bayley III } \\
\text { Griffith } \\
\text { Other }\end{array}$ & Mandatory & $\begin{array}{l}\text { Type of } \\
\text { developmental test } \\
\text { performed }\end{array}$ \\
\hline
\end{tabular}




\begin{tabular}{|c|c|c|c|c|c|}
\hline Module(s) & Common Data Element & Format & Standardized response options & Importance & $\begin{array}{l}\text { Comment / } \\
\text { Description }\end{array}$ \\
\hline $\begin{array}{l}\text { Metabolic diseases } \\
\text { Neurology }\end{array}$ & Development test: Results & normal/abnormal & & Mandatory & $\begin{array}{l}\text { Result of } \\
\text { developmental test } \\
\text { performed }\end{array}$ \\
\hline Metabolic diseases & Developmental delay & yes/no & & Mandatory & $\begin{array}{l}\text { Developmental delay } \\
\text { as assessed by } \\
\text { treating physician }\end{array}$ \\
\hline Nephrology & CKD stage & number & & Mandatory & $\begin{array}{l}\text { Chronic Kidney } \\
\text { Disease stage }\end{array}$ \\
\hline Pulmonology & Epworth Sleepiness Scale & number & & Mandatory & \\
\hline Pulmonology & Lung-to-Head-Ratio & number & & Mandatory & $\begin{array}{l}\text { Congenital } \\
\text { diaphragmatic hernia }\end{array}$ \\
\hline Pulmonology & PICADAR & number & & Mandatory & $\begin{array}{l}\text { PrImary CiliARy } \\
\text { DyskinesiA Rule }\end{array}$ \\
\hline \multicolumn{6}{|c|}{ Domain: Investigations } \\
\hline General paediatrics & Type of radiological study (detailed) & $\begin{array}{l}\text { standardized } \\
\text { options }\end{array}$ & See comments & Mandatory & $\begin{array}{l}\text { Standard } \\
\text { classification to be } \\
\text { defined }\end{array}$ \\
\hline General paediatrics & Date and time of imaging study & datetime & YYYY-MM-DD hh:mm:ss & Mandatory & $\begin{array}{l}\text { Date and time of the } \\
\text { radiological study }\end{array}$ \\
\hline General paediatrics & Radiation dose & number & & Mandatory & $\begin{array}{l}\text { If applicable, dose of } \\
\text { radiation in } \mathrm{mSv}\end{array}$ \\
\hline General paediatrics & Indication for the imaging study & free text & & Mandatory & $\begin{array}{l}\text { Medical reason for } \\
\text { the radiological study }\end{array}$ \\
\hline Cardiology & ECG performed & yes/no & & Mandatory & $\begin{array}{l}\text { Date of study should } \\
\text { be recorded }\end{array}$ \\
\hline Cardiology & Holter-ECG & yes/no & & Mandatory & $\begin{array}{l}\text { Date of study should } \\
\text { be recorded }\end{array}$ \\
\hline Cardiology & Ergometry & yes/no & & Mandatory & $\begin{array}{l}\text { Date of study should } \\
\text { be recorded }\end{array}$ \\
\hline Cardiology & Echocardiography performed & yes/no & & Mandatory & $\begin{array}{l}\text { Detailed } \\
\text { standardized echo } \\
\text { measurements will } \\
\text { be discussed in the } \\
\text { future. Date of study } \\
\text { should be recorded }\end{array}$ \\
\hline Cardiology & Cardiac electrophysiology study performed & yes/no & & Mandatory & $\begin{array}{l}\text { Date of study should } \\
\text { be recorded }\end{array}$ \\
\hline Cardiology & $\begin{array}{l}\text { Diagnostic cardiac catheterization (hemodynamic study) } \\
\text { performed }\end{array}$ & yes/no & & Mandatory & $\begin{array}{l}\text { Date of study should } \\
\text { be recorded }\end{array}$ \\
\hline
\end{tabular}




\begin{tabular}{|c|c|c|c|c|c|}
\hline Module(s) & Common Data Element & Format & Standardized response options & Importance & $\begin{array}{l}\text { Comment / } \\
\text { Description }\end{array}$ \\
\hline Endocrinology & Bone age: method & $\begin{array}{l}\text { standardized } \\
\text { options }\end{array}$ & $\begin{array}{l}\text { Greulich \& Pyle } \\
\text { BoneXpertR } \\
\text { Tanner Whitehouse }\end{array}$ & Mandatory & $\begin{array}{l}\text { Method used to } \\
\text { assess radiographic } \\
\text { bone age. Date of } \\
\text { study should be } \\
\text { recorded }\end{array}$ \\
\hline Endocrinology & Bone age: result & number & & Mandatory & $\begin{array}{l}\text { Bone age result in } \\
\text { years }\end{array}$ \\
\hline $\begin{array}{l}\text { Endocrinology } \\
\text { Metabolic diseases }\end{array}$ & Use of continuous glucose monitoring & yes/no & & $\begin{array}{l}\text { Recommende } \\
\text { d }\end{array}$ & Use of glucose sensor \\
\hline Endocrinology & $\begin{array}{l}\text { Number of days per week with continuous glucose } \\
\text { monitoring }\end{array}$ & number & & Mandatory & Days per week \\
\hline Endocrinology & Continuous glucose monitoring: Device & $\begin{array}{l}\text { standardized } \\
\text { options }\end{array}$ & $\begin{array}{l}\text { Freestyle libre } \\
\text { Freestyle libre } 2 \\
\text { Dexcom G5 } \\
\text { Dexcom G6 } \\
\text { Medtronic Guardian } \\
\text { Medtronic Enlyte } \\
\end{array}$ & Mandatory & \\
\hline Endocrinology & Blood glucose self-measurement & number & & Mandatory & $\begin{array}{l}\text { Number of measures } \\
\text { per week }\end{array}$ \\
\hline Endocrinology & Scans per day & number & & Mandatory & $\begin{array}{l}\text { If Flash Glucose } \\
\text { Monitoring (FGM) is } \\
\text { used }\end{array}$ \\
\hline Endocrinology & Blood ketone measurement & number & & Mandatory & $\begin{array}{l}\text { Number of measures } \\
\text { per week }\end{array}$ \\
\hline Endocrinology & Mean glucose & number & & Mandatory & $\mathrm{mmol} / \mathrm{l}$ \\
\hline Endocrinology & Glucose variability & number & & Mandatory & $\%$ \\
\hline Endocrinology & Time in range & number & & Mandatory & $\begin{array}{l}\text { Time between } 4.0 \\
\text { and } 10.0 \mathrm{mmol} / \mathrm{l} \text { in \% }\end{array}$ \\
\hline Endocrinology & Time in hypoglycemia & number & & Mandatory & $\begin{array}{l}\text { Time }<3.9 \mathrm{mmol} / \mathrm{l} \text { in } \\
\%\end{array}$ \\
\hline Gastroenterology & Type of gastrointestinal endoscopy & $\begin{array}{l}\text { standardized } \\
\text { options }\end{array}$ & $\begin{array}{l}\text { Upper } \\
\text { Lower } \\
\text { Upper and lower } \\
\text { Other } \\
\end{array}$ & Mandatory & $\begin{array}{l}\text { Date of study should } \\
\text { be recorded }\end{array}$ \\
\hline Gastroenterology & Indication for gastrointestinal endoscopy & $\begin{array}{l}\text { standardized } \\
\text { options }\end{array}$ & $\begin{array}{l}\text { Rectal bleeding } \\
\text { Abdominal pain } \\
\text { Dysphagia } \\
\text { Diarrhea } \\
\text { Other }\end{array}$ & Mandatory & $\begin{array}{l}\text { Medical reason for } \\
\text { the endoscopic } \\
\text { study. Other include } \\
\text { for example } \\
\text { oesophageal atresia } \\
\text { or other anatomical } \\
\text { abnormality, food } \\
\text { impaction }\end{array}$ \\
\hline
\end{tabular}




\begin{tabular}{|c|c|c|c|c|c|}
\hline Module(s) & Common Data Element & Format & Standardized response options & Importance & $\begin{array}{l}\text { Comment / } \\
\text { Description }\end{array}$ \\
\hline Gastroenterology & Gastrointestinal endoscopic biopsy & yes/no & & Mandatory & $\begin{array}{l}\text { Gastrointestinal } \\
\text { endoscopic biopsy } \\
\text { performed. Date of } \\
\text { study should be } \\
\text { recorded }\end{array}$ \\
\hline Gastroenterology & Impedance-pHmetry & yes/no & & Mandatory & $\begin{array}{l}\text { Date of study should } \\
\text { be recorded }\end{array}$ \\
\hline Gastroenterology & Type of breath test & $\begin{array}{l}\text { standardized } \\
\text { options }\end{array}$ & $\begin{array}{l}\text { Lactose } \\
\text { Lactulose } \\
\text { Fructose } \\
\text { Urea } \\
\text { Other } \\
\end{array}$ & Mandatory & $\begin{array}{l}\text { Type of breath test. } \\
\text { Date of study should } \\
\text { be recorded }\end{array}$ \\
\hline Gastroenterology & Capsule endoscopy & yes/no & & Mandatory & $\begin{array}{l}\text { Date of study should } \\
\text { be recorded }\end{array}$ \\
\hline Gastroenterology & Endoscopic ultrasound & yes/no & & Mandatory & $\begin{array}{l}\text { Date of study should } \\
\text { be recorded }\end{array}$ \\
\hline Gastroenterology & Liver biopsy & yes/no & & Mandatory & $\begin{array}{l}\text { Date of study should } \\
\text { be recorded }\end{array}$ \\
\hline Allergy/Immunology & Prick-test performed & yes/no & & Mandatory & $\begin{array}{l}\text { Date of study should } \\
\text { be recorded }\end{array}$ \\
\hline $\begin{array}{l}\text { Allergy/Immunology } \\
\text { Pulmonology }\end{array}$ & slgE performed & yes/no & & Mandatory & $\begin{array}{l}\text { slgE stands for } \\
\text { specific serum } \\
\text { immunoglobulin E. } \\
\text { Date of study should } \\
\text { be recorded }\end{array}$ \\
\hline Allergy/Immunology & Result of slgE & positive/negative & & Mandatory & $\begin{array}{l}\text { slgE stands for } \\
\text { specific serum } \\
\text { immunoglobulin E }\end{array}$ \\
\hline Allergy/Immunology & Result of prick-test & positive/negative & & Mandatory & $\begin{array}{l}\text { Date of study should } \\
\text { be recorded }\end{array}$ \\
\hline Allergy/Immunology & Allergen challenge performed & yes/no & & Mandatory & $\begin{array}{l}\text { Date of study should } \\
\text { be recorded }\end{array}$ \\
\hline Allergy/Immunology & Allergen challenge result & positive/negative & & Mandatory & \\
\hline Infectious diseases & Urine collection method & $\begin{array}{l}\text { standardized } \\
\text { options }\end{array}$ & $\begin{array}{l}\text { Urethral catheterization } \\
\text { Clean catch void } \\
\text { Urine collection bag } \\
\text { Mid-stream urine } \\
\text { Suprapubic aspiration }\end{array}$ & Mandatory & $\begin{array}{l}\text { Method of collection } \\
\text { of urine for culture. } \\
\text { Date of study should } \\
\text { be recorded }\end{array}$ \\
\hline Infectious diseases & Mantoux test & number & & Mandatory & $\begin{array}{l}\text { In } \mathrm{mm} \text {. Date of study } \\
\text { should be recorded }\end{array}$ \\
\hline Infectious diseases & Mantoux test: interpretation & $\begin{array}{l}\text { standardized } \\
\text { options }\end{array}$ & $\begin{array}{l}\text { Positive } \\
\text { Negative } \\
\text { Doubtful } \\
\text { Unknown }\end{array}$ & Mandatory & $\begin{array}{l}\text { Healthcare provider's } \\
\text { interpretation of } \\
\text { Mantoux test }\end{array}$ \\
\hline
\end{tabular}




\begin{tabular}{|c|c|c|c|c|c|}
\hline Module(s) & Common Data Element & Format & Standardized response options & Importance & $\begin{array}{l}\text { Comment / } \\
\text { Description }\end{array}$ \\
\hline Infectious diseases & IGRA result & $\begin{array}{l}\text { standardized } \\
\text { options }\end{array}$ & $\begin{array}{l}\text { Positive } \\
\text { Negative } \\
\text { Indeterminate }\end{array}$ & Mandatory & $\begin{array}{l}\text { IGRA stands for } \\
\text { Interferon-Gamma } \\
\text { Release Assay. Date } \\
\text { of study should be } \\
\text { recorded }\end{array}$ \\
\hline Nephrology & Renal ultrasound result & normal/abnormal & & Mandatory & $\begin{array}{l}\text { Date of study should } \\
\text { be recorded }\end{array}$ \\
\hline Nephrology & Renal MRI result & normal/abnormal & & Mandatory & $\begin{array}{l}\text { Date of study should } \\
\text { be recorded }\end{array}$ \\
\hline Nephrology & $\begin{array}{l}\text { Voiding cystourethrography or kidney microbubble } \\
\text { ultrasound results }\end{array}$ & $\begin{array}{l}\text { standardized } \\
\text { options }\end{array}$ & $\begin{array}{l}\text { No vesicoureteral reflux } \\
\text { Vesicoureteral reflux, unilateral - Grade I } \\
\text { Vesicoureteral reflux, unilateral - Grade II } \\
\text { Vesicoureteral reflux, unilateral - Grade III } \\
\text { Vesicoureteral reflux, unilateral - Grade IV } \\
\text { Vesicoureteral reflux, bilateral - Grade I } \\
\text { Vesicoureteral reflux, bilateral - Grade II } \\
\text { Vesicoureteral reflux, bilateral - Grade III } \\
\text { Vesicoureteral reflux, bilateral - Grade IV }\end{array}$ & Mandatory & $\begin{array}{l}\text { Date of study should } \\
\text { be recorded }\end{array}$ \\
\hline Nephrology & Posterior urethral valves & yes/no & & & \\
\hline Nephrology & Renal scintigraphy results & $\begin{array}{l}\text { standardized } \\
\text { options }\end{array}$ & $\begin{array}{l}\text { Normal } \\
\text { Hypoplasia } \\
\text { Scars } \\
\text { Other }\end{array}$ & Mandatory & $\begin{array}{l}\text { Date of study should } \\
\text { be recorded }\end{array}$ \\
\hline Nephrology & Estimated GFR by Schwartz formula & number & & Mandatory & GFR [ml/min] \\
\hline Nephrology & Proteinuria & number & & Mandatory & $\begin{array}{l}\text { In } \mathrm{mg} / \mathrm{mmol} \text { (spot- } \\
\text { urine) or } \mathrm{mg} / \mathrm{m} 2 / \mathrm{h} \\
\text { for } 24 \mathrm{~h} \text { Urine }\end{array}$ \\
\hline $\begin{array}{l}\text { Nephrology } \\
\text { Neurology } \\
\text { Pulmonology }\end{array}$ & Genetic test performed & yes/no & & $\begin{array}{l}\text { Mandatory } \\
\text { Recommende } \\
\text { d }\end{array}$ & $\begin{array}{l}\text { Mandatory for } \\
\text { nephrology, } \\
\text { recommended for } \\
\text { neurology and } \\
\text { pulmonology }\end{array}$ \\
\hline Neurology & Neurologic electrophysiologic study: Type & $\begin{array}{l}\text { standardized } \\
\text { options }\end{array}$ & $\begin{array}{l}\text { EEG } \\
\text { EMG } \\
\text { AEP } \\
\text { SEP } \\
\text { VEP } \\
\text { Other }\end{array}$ & Mandatory & $\begin{array}{l}\text { EEG: } \\
\text { electroencephalogra } \\
\text { m, EMG: } \\
\text { electromyography, } \\
\text { AEP: auditory evoked } \\
\text { potentials, SEP: } \\
\text { somatosensory } \\
\text { evoked potentials, } \\
\text { VEP: visual evoked } \\
\text { potential } \\
\text { Date of study should } \\
\text { be recorded }\end{array}$ \\
\hline
\end{tabular}




\begin{tabular}{|c|c|c|c|c|c|}
\hline Module(s) & Common Data Element & Format & Standardized response options & Importance & $\begin{array}{l}\text { Comment / } \\
\text { Description }\end{array}$ \\
\hline Neurology & Neurologic electrophysiologic study: Result & normal/abnormal & & Mandatory & \\
\hline $\begin{array}{l}\text { Metabolic diseases } \\
\text { Neurology }\end{array}$ & Hearing test: Type & $\begin{array}{l}\text { standardized } \\
\text { options }\end{array}$ & $\begin{array}{l}\text { OAE } \\
\text { AEP } \\
\text { Pure tone audiometry }\end{array}$ & Mandatory & $\begin{array}{l}\text { OAE: otoacoustic } \\
\text { emissions, AEP: } \\
\text { auditory evoked } \\
\text { potentials } \\
\text { Date of study should } \\
\text { be recorded }\end{array}$ \\
\hline $\begin{array}{l}\text { Metabolic diseases } \\
\text { Neurology }\end{array}$ & Hearing test: Result & normal/abnormal & & Mandatory & \\
\hline Neurology & Vision test: Performed by & $\begin{array}{l}\text { standardized } \\
\text { options }\end{array}$ & $\begin{array}{l}\text { Ophtalmologist } \\
\text { Optometrist } \\
\text { Peadiatrician } \\
\text { Other }\end{array}$ & $\begin{array}{l}\text { Recommende } \\
\text { d }\end{array}$ & $\begin{array}{l}\text { Health professional } \\
\text { who tested vision }\end{array}$ \\
\hline Neurology & Vision test: Result & normal/abnormal & & $\begin{array}{l}\text { Recommende } \\
\mathrm{d}\end{array}$ & \\
\hline Neurology & Lumbar puncture performed & yes/no & & Mandatory & $\begin{array}{l}\text { Date of study should } \\
\text { be recorded }\end{array}$ \\
\hline Neurology & Opening Pressure at Lumbar Puncture & number & & Optional & $\begin{array}{l}\text { Opening pressure in } \\
\mathrm{cmH} 2 \mathrm{O}\end{array}$ \\
\hline Pulmonology & Spirometry performed & yes/no & & Mandatory & $\begin{array}{l}\text { Date of study should } \\
\text { be recorded }\end{array}$ \\
\hline Pulmonology & Lung function: RV & number & & $\begin{array}{l}\text { Recommende } \\
\text { d }\end{array}$ & $\begin{array}{l}\text { RV: Residual volume. } \\
\text { In L }\end{array}$ \\
\hline Pulmonology & DLCO & number & Diffusion capacity of the lung for carbon monoxide & $\begin{array}{l}\text { Recommende } \\
\text { d }\end{array}$ & $\begin{array}{l}\text { DLCO: diffusing } \\
\text { capacity of the lungs } \\
\text { for carbon monoxide. } \\
\text { In } \mathrm{ml} \mathrm{CO} / \mathrm{min} / \mathrm{mmHg}\end{array}$ \\
\hline Pulmonology & Lung function: Bronchodilator administered & yes/no & & Mandatory & \\
\hline Pulmonology & Bronchoscopy performed & yes/no & & Mandatory & $\begin{array}{l}\text { Date of study should } \\
\text { be recorded }\end{array}$ \\
\hline Pulmonology & $\begin{array}{l}\text { Lung function: Challenge test performed (treadmill, } \\
\text { methacholine challenge test) }\end{array}$ & yes/no & & Mandatory & \\
\hline Pulmonology & Broncho-alveolar lavage performed & yes/no & & Mandatory & \\
\hline Pulmonology & Sweat test results & $\begin{array}{l}\text { standardized } \\
\text { options }\end{array}$ & & Mandatory & $\begin{array}{l}\text { Chloride in } \mathrm{mmol} / \mathrm{l} \\
\text { (Macroduct) } \\
\text { Conductivity in } \\
\mathrm{mmol} / \mathrm{l} \mathrm{eq} \mathrm{NaCl} \\
\text { (Nanoduct) } \\
\text { Date of study should } \\
\text { be recorded }\end{array}$ \\
\hline
\end{tabular}




\begin{tabular}{|c|c|c|c|c|c|}
\hline Module(s) & Common Data Element & Format & Standardized response options & Importance & $\begin{array}{l}\text { Comment / } \\
\text { Description }\end{array}$ \\
\hline Pulmonology & Sleep studies & $\begin{array}{l}\text { standardized } \\
\text { options }\end{array}$ & $\begin{array}{l}\text { Polysomnography } \\
\text { Respiratory Polygraphy } \\
\text { Oximetry }\end{array}$ & Mandatory & $\begin{array}{l}\text { Sleep studies } \\
\text { performed } \\
\text { Date of study should } \\
\text { be recorded }\end{array}$ \\
\hline Pulmonology & Lung function: FEV1 & number & & Mandatory & $\begin{array}{l}\text { FEV1: forced } \\
\text { expiratory volume- } \\
\text { one second. pre/post } \\
\text { absolute number in L }\end{array}$ \\
\hline Pulmonology & Lung function: FVC & number & & Mandatory & $\begin{array}{l}\text { FVC: forced vital } \\
\text { capacity. Pre/post. In } \\
\text { L }\end{array}$ \\
\hline Pulmonology & Lung function: TLC & number & & $\begin{array}{l}\text { Recommende } \\
\mathrm{d}\end{array}$ & $\begin{array}{l}\text { TLC: Total lung } \\
\text { capacity. In L }\end{array}$ \\
\hline Pulmonology & Lung function: $\mathrm{LCl}$ & number & & $\begin{array}{l}\text { Recommende } \\
\text { d }\end{array}$ & $\begin{array}{l}\text { LCl: Lung clearance } \\
\text { index. Equipment / } \\
\text { gas currently in use } \\
\text { in each center }\end{array}$ \\
\hline Pulmonology & Lung function: Nasal NO & number & & $\begin{array}{l}\text { Recommende } \\
d\end{array}$ & $\begin{array}{l}\text { Nasal NO: Nasal nitric } \\
\text { oxide measurement. } \\
\text { in ppb or } \mathrm{nl} / \mathrm{mn}\end{array}$ \\
\hline Pulmonology & Lung function: FeNO & number & & $\begin{array}{l}\text { Recommende } \\
\text { d }\end{array}$ & $\begin{array}{l}\text { FeNO: exhaled nitric } \\
\text { oxide test. Online or } \\
\text { Off-line method. } \\
\text { absolute number in } \\
\text { ppb }\end{array}$ \\
\hline Pulmonology & Lung function: CPET performed & yes/no & & $\begin{array}{l}\text { Recommende } \\
d\end{array}$ & $\begin{array}{l}\text { CPET: } \\
\text { Cardiopulmonary } \\
\text { Exercise Testing } \\
\end{array}$ \\
\hline Pulmonology & Lung function: FEF 25-75 & number & & $\begin{array}{l}\text { Recommende } \\
d\end{array}$ & $\begin{array}{l}\text { FEF25-75: Forced } \\
\text { expiratory flow over } \\
\text { the middle one half } \\
\text { of the FVC (force vital } \\
\text { capacity). in L/s }\end{array}$ \\
\hline Pulmonology & Lung function: FEV 0.75 & number & & $\begin{array}{l}\text { Recommende } \\
\text { d }\end{array}$ & $\begin{array}{l}\text { FEV } 0.75 \text { : forced } \\
\text { expiratory volume in } \\
3 / 4 \text { of a second. } \\
\text { pre/post. absolute } \\
\text { number in } \mathrm{L}\end{array}$ \\
\hline Pulmonology & Lung function: sRaw & number & & $\begin{array}{l}\text { Recommende } \\
\mathrm{d}\end{array}$ & $\begin{array}{l}\text { sRaw: specific airway } \\
\text { resistance. } \mathrm{kPa} / \mathrm{sec}\end{array}$ \\
\hline Pulmonology & Lung function: FRC & number & & $\begin{array}{l}\text { Recommende } \\
\mathrm{d}\end{array}$ & $\begin{array}{l}\text { FRC: functional } \\
\text { residual capacity. in L }\end{array}$ \\
\hline Pulmonology & Lung function: FRC: Test & $\begin{array}{l}\text { standardized } \\
\text { options }\end{array}$ & $\begin{array}{l}\text { Bodyplethysmography } \\
\text { MBW }\end{array}$ & $\begin{array}{l}\text { Recommende } \\
\mathrm{d}\end{array}$ & $\begin{array}{l}\text { MBW: multiple } \\
\text { breath washout }\end{array}$ \\
\hline
\end{tabular}


Domain: Diagnosis

\begin{tabular}{|c|c|c|c|c|c|}
\hline General paediatrics & Diagnosis & See comments & See comments & Mandatory & $\begin{array}{l}\text { Inpatients diagnosis } \\
\text { are ICD10 coded and } \\
\text { outpatients diagnosis } \\
\text { are free text. }\end{array}$ \\
\hline General paediatrics & Date of diagnosis & date & YYYY-MM-DD & Mandatory & \\
\hline General paediatrics & Cause of death & See comments & See comments & Mandatory & $\begin{array}{l}\text { Standard } \\
\text { classification to be } \\
\text { defined }\end{array}$ \\
\hline General paediatrics & Date of death & date & YYYY-MM-DD & Mandatory & \\
\hline Cardiology & IPCCC diagnosis & $\begin{array}{l}\text { standardized } \\
\text { options }\end{array}$ & IPCCC Code & Mandatory & $\begin{array}{l}\text { IPCCC: International } \\
\text { Paediatric and } \\
\text { Congenital Cardiac } \\
\text { Code }\end{array}$ \\
\hline Allergy/Immunology & Allergic disease confirmation & $\begin{array}{l}\text { standardized } \\
\text { options }\end{array}$ & $\begin{array}{l}\text { Skin prick test } \\
\text { Allergen challenge } \\
\text { slgE }\end{array}$ & Mandatory & \\
\hline Infectious diseases & If infectious diagnosis: Type of documentation & $\begin{array}{l}\text { standardized } \\
\text { options }\end{array}$ & $\begin{array}{l}\text { Clinically documented infection } \\
\text { Microbiologically documented infection }\end{array}$ & Mandatory & \\
\hline Infectious diseases & If infectious diagnosis: Nosocomial & yes/no & & Mandatory & \\
\hline Infectious diseases & If nosocomial infection: Date of first symptom & date & YYYY-MM-DD & Mandatory & \\
\hline Infectious diseases & If nosocomial infection: Site of infection & $\begin{array}{l}\text { standardized } \\
\text { options }\end{array}$ & $\begin{array}{l}\text { Respiratory tract } \\
\text { Gastro-intestinal tract } \\
\text { Urinary tract } \\
\text { Surgical site } \\
\text { Other }\end{array}$ & Mandatory & \\
\hline Metabolic diseases & Diagnosis confirmation & $\begin{array}{l}\text { standardized } \\
\text { options }\end{array}$ & $\begin{array}{l}\text { Clinical } \\
\text { Biochemical } \\
\text { Enzymatic } \\
\text { Genetic }\end{array}$ & Mandatory & $\begin{array}{l}\text { The way diagnosis } \\
\text { has been confirmed }\end{array}$ \\
\hline Metabolic diseases & Diagnosis suspicion & $\begin{array}{l}\text { standardized } \\
\text { options }\end{array}$ & $\begin{array}{l}\text { Prenatal } \\
\text { Newborn } \\
\text { Selective }\end{array}$ & Mandatory & $\begin{array}{l}\text { The type of screening } \\
\text { that led to the } \\
\text { diagnosis }\end{array}$ \\
\hline Neurology & OMIM code & $\begin{array}{l}\text { standardized } \\
\text { options }\end{array}$ & OMIM code & $\begin{array}{l}\text { Recommende } \\
\text { d }\end{array}$ & $\begin{array}{l}\text { OMIM: Online } \\
\text { Mendelian } \\
\text { Inheritance in Man }\end{array}$ \\
\hline Neurology & HPO code & $\begin{array}{l}\text { standardized } \\
\text { options }\end{array}$ & HPO code & Optional & $\begin{array}{l}\text { HPO: Human } \\
\text { Phenotype Ontology }\end{array}$ \\
\hline
\end{tabular}




\begin{tabular}{|c|c|c|c|c|c|}
\hline Module(s) & Common Data Element & Format & Standardized response options & Importance & $\begin{array}{l}\text { Comment / } \\
\text { Description }\end{array}$ \\
\hline General paediatrics & Drug name & $\begin{array}{l}\text { standardized } \\
\text { options }\end{array}$ & International non-proprietary name & Mandatory & $\begin{array}{l}\text { Name of the drug(s) } \\
\text { received as inpatient }\end{array}$ \\
\hline General paediatrics & Prescribed drug at discharge & $\begin{array}{l}\text { standardized } \\
\text { options }\end{array}$ & International non-proprietary name & Mandatory & $\begin{array}{l}\text { Name of the drug(s) } \\
\text { prescribed at } \\
\text { discharge }\end{array}$ \\
\hline General paediatrics & Route of administration & $\begin{array}{l}\text { standardized } \\
\text { options }\end{array}$ & $\begin{array}{l}\text { Oral } \\
\text { Intravenous } \\
\text { Subcutaneous } \\
\text { Intramuscular } \\
\text { Intrathecal } \\
\text { Rectal } \\
\text { Inhalation } \\
\text { Cutaneous } \\
\text { Ocular } \\
\text { Nasal } \\
\text { Otic } \\
\text { Other }\end{array}$ & Mandatory & \\
\hline General paediatrics & Date and time of first administration & datetime & YYYY-MM-DD hh:mm:ss & Mandatory & $\begin{array}{l}\text { Time of first } \\
\text { administration of the } \\
\text { drug }\end{array}$ \\
\hline General paediatrics & Date and time of last administration & datetime & YYYY-MM-DD hh:mm:ss & Mandatory & $\begin{array}{l}\text { Time of last } \\
\text { administration of the } \\
\text { drug }\end{array}$ \\
\hline General paediatrics & Frequency of administration & number & & Mandatory & $\begin{array}{l}\text { Number of } \\
\text { administrations per } \\
24 \text { hours }\end{array}$ \\
\hline General paediatrics & Dose & number & & Mandatory & $\begin{array}{l}\text { Dose given at each } \\
\text { administration of the } \\
\text { drug }\end{array}$ \\
\hline General paediatrics & Dose unit & $\begin{array}{l}\text { standardized } \\
\text { options }\end{array}$ & & Mandatory & $\begin{array}{l}\text { List of possible units } \\
\text { to be defined }\end{array}$ \\
\hline General paediatrics & Reason for discontinuation of treatment & $\begin{array}{l}\text { standardized } \\
\text { options }\end{array}$ & $\begin{array}{l}\text { Recovery } \\
\text { Change to another medication } \\
\text { No effect observable } \\
\text { Adverse events } \\
\text { Reducing polypharmacy } \\
\text { Other } \\
\end{array}$ & Mandatory & $\begin{array}{l}\text { Reason why a } \\
\text { treatment is stopped }\end{array}$ \\
\hline General paediatrics & Adverse events & $\begin{array}{l}\text { standardized } \\
\text { options }\end{array}$ & MedDRA classification & Mandatory & $\begin{array}{l}\text { MedDRA: Medical } \\
\text { Dictionary for } \\
\text { Regulatory Activities }\end{array}$ \\
\hline General paediatrics & Supplemental 02: Date and time of start & datetime & YYYY-MM-DD hh:mm:ss & Mandatory & $\begin{array}{l}\text { Time at starting } \\
\text { oxygen therapy }\end{array}$ \\
\hline General paediatrics & Supplemental 02: Date and time of interruption & datetime & YYYY-MM-DD hh:mm:ss & Mandatory & $\begin{array}{l}\text { Time at stopping } \\
\text { oxygen therapy }\end{array}$ \\
\hline
\end{tabular}




\begin{tabular}{|c|c|c|c|c|c|}
\hline Module(s) & Common Data Element & Format & Standardized response options & Importance & $\begin{array}{l}\text { Comment / } \\
\text { Description }\end{array}$ \\
\hline General paediatrics & Supportive services: Type & $\begin{array}{l}\text { standardized } \\
\text { options }\end{array}$ & $\begin{array}{l}\text { Physiotherapy } \\
\text { Ergotherapy } \\
\text { Social assistance } \\
\text { Other }\end{array}$ & Mandatory & \\
\hline Endocrinology & Type of insuline therapy & $\begin{array}{l}\text { standardized } \\
\text { options }\end{array}$ & $\begin{array}{l}\mathrm{MDI} \\
\mathrm{CSII}\end{array}$ & Mandatory & $\begin{array}{l}\text { MDI: Multiple dose } \\
\text { injection. CSII: } \\
\text { Continuous } \\
\text { subcutaneous insulin } \\
\text { infusion }\end{array}$ \\
\hline Endocrinology & Total daily dose of insuline (long and short acting) & number & & Mandatory & units per kg per day \\
\hline Endocrinology & Basal insuline & number & & Mandatory & $\begin{array}{l}\text { Percentage of basal } \\
\text { insuline (\%) }\end{array}$ \\
\hline $\begin{array}{l}\text { Gastroenterology } \\
\text { Metabolic diseases }\end{array}$ & Therapeutic diet & yes/no & & Mandatory & $\begin{array}{l}\text { Therapeutic diet } \\
\text { prescribed by } \\
\text { physician }\end{array}$ \\
\hline Metabolic diseases & Type of therapeutic diet & $\begin{array}{l}\text { standardized } \\
\text { options }\end{array}$ & $\begin{array}{l}\text { Low-protein } \\
\text { Ketogenic } \\
\text { Low-fat } \\
\text { Frequent meals } \\
\text { Nocturnal feed } \\
\text { Medical food } \\
\text { Other } \\
\end{array}$ & Mandatory & $\begin{array}{l}\text { Type of therapeutic } \\
\text { diet prescribed }\end{array}$ \\
\hline Allergy/Immunology & Epinephrine Pen prescribed & yes/no & & & \\
\hline Infectious diseases & BCG immunization & $\begin{array}{l}\text { standardized } \\
\text { options }\end{array}$ & $\begin{array}{l}\text { Yes } \\
\text { No } \\
\text { Unknown }\end{array}$ & Mandatory & \\
\hline Neurology & Rehabilitation supportive devices: Type & $\begin{array}{l}\text { standardized } \\
\text { options }\end{array}$ & $\begin{array}{l}\text { Upper limb orthoses } \\
\text { Lower limb orthoses } \\
\text { Corset } \\
\text { Standing frame } \\
\text { Walking aid (crutches NF-walker, rollator etc.) } \\
\text { Wheelchair: Manual } \\
\text { Wheelchair: Electric powered } \\
\text { Other }\end{array}$ & $\begin{array}{l}\text { Recommende } \\
\text { d }\end{array}$ & \\
\hline Pulmonology & Pulmonary rehabilitation & yes/no & & $\begin{array}{l}\text { Recommende } \\
\text { d }\end{array}$ & \\
\hline \multicolumn{6}{|c|}{ Domain: Equipment and procedures } \\
\hline General paediatrics & Equipment type & $\begin{array}{l}\text { standardized } \\
\text { options }\end{array}$ & See comments & Mandatory & $\begin{array}{l}\text { Standard } \\
\text { classification to be } \\
\text { defined }\end{array}$ \\
\hline General paediatrics & Equipment date of insertion & date & YYYY-MM-DD & Mandatory & \\
\hline General paediatrics & Equipment date of withdrawal & date & YYYY-MM-DD & Mandatory & \\
\hline
\end{tabular}




\begin{tabular}{|c|c|c|c|c|c|}
\hline Module(s) & Common Data Element & Format & Standardized response options & Importance & $\begin{array}{l}\text { Comment / } \\
\text { Description }\end{array}$ \\
\hline Cardiology & Cardiac procedures & $\begin{array}{l}\text { standardized } \\
\text { options }\end{array}$ & IPCCC Code & Mandatory & $\begin{array}{l}\text { IPCCC: International } \\
\text { Paediatric and } \\
\text { Congenital Cardiac } \\
\text { Code }\end{array}$ \\
\hline Cardiology & Date of cardiac procedure & date & YYYY-MM-DD & Mandatory & Date of intervention \\
\hline Gastroenterology & Therapeutic gastrointestinal endoscopic procedures & $\begin{array}{l}\text { standardized } \\
\text { options }\end{array}$ & $\begin{array}{l}\text { Haemostasis } \\
\text { Oesophageal dilatation (Balloon/Savary) } \\
\text { Percutaneous endoscopic gastrostomy (PEG) } \\
\text { Endoscopic retrograde cholangiopancreatography } \\
\text { (ERCP) } \\
\text { Other }\end{array}$ & Mandatory & \\
\hline Nephrology & Type of dialysis (1) & $\begin{array}{l}\text { standardized } \\
\text { options }\end{array}$ & $\begin{array}{l}\text { Acute } \\
\text { Chronic }\end{array}$ & Mandatory & \\
\hline Nephrology & Type of dialysis (2) & $\begin{array}{l}\text { standardized } \\
\text { options }\end{array}$ & $\begin{array}{l}\text { Haemodialysis } \\
\text { Peritoneal dialysis } \\
\text { Hemodiafiltration }\end{array}$ & Mandatory & $\begin{array}{l}\text { If peritoneal dialysis, } \\
\text { type of catheter and } \\
\text { number of peritonitis } \\
\text { should be specified }\end{array}$ \\
\hline Nephrology & Date of dialysis initiation & datetime & YYYY-MM-DD hh:mm:ss & Mandatory & \\
\hline Nephrology & Date of dialysis termination & datetime & YYYY-MM-DD hh:mm:ss & Mandatory & \\
\hline Nephrology & Dialysis: vascular access type & $\begin{array}{l}\text { standardized } \\
\text { option }\end{array}$ & $\begin{array}{l}\text { Central venous catheter } \\
\text { Arteriovenous fistula } \\
\text { Arteriovenous graft }\end{array}$ & Mandatory & $\begin{array}{l}\text { If central venous } \\
\text { catheter, its } \\
\text { localization should be } \\
\text { specified }\end{array}$ \\
\hline Nephrology & Renal transplantation, graft (1) & $\begin{array}{l}\text { standardized } \\
\text { options }\end{array}$ & $\begin{array}{l}\text { Deceased donor } \\
\text { Living donor }\end{array}$ & Mandatory & \\
\hline Nephrology & Renal transplantation, graft (2) & $\begin{array}{l}\text { standardized } \\
\text { options }\end{array}$ & $\begin{array}{l}\text { Related donor } \\
\text { Unrelated donor }\end{array}$ & Mandatory & \\
\hline Nephrology & Renal transplantation & $\begin{array}{l}\text { standardized } \\
\text { options }\end{array}$ & $\begin{array}{l}\text { Preemptive transplantation } \\
\text { Nonpreemptive transplantation }\end{array}$ & Mandatory & \\
\hline Nephrology & Renal transplantation: Number of received grafts & number & & Mandatory & $\begin{array}{l}\text { Number of grafts } \\
\text { received including } \\
\text { present one }\end{array}$ \\
\hline Nephrology & Plasmapheresis performed & yes/no & & Mandatory & \\
\hline Nephrology & Renal biopsy performed & $\begin{array}{l}\text { standardized } \\
\text { options }\end{array}$ & $\begin{array}{l}\text { No } \\
\text { Yes, without complication in the following } 24 \text { hours } \\
\text { Yes, with complications in the following } 24 \text { hours }\end{array}$ & Mandatory & \\
\hline Nephrology & Cystoscopy performed & yes/no & & Mandatory & \\
\hline Nephrology & Angiography performed & yes/no & & Mandatory & \\
\hline
\end{tabular}

